\title{
Mathematical Simulation of Forest Fire Impact on Industrial Facilities and Wood-Based Buildings
}

\author{
Nikolay Baranovskiy *(i) and Aleksey Malinin \\ School of Energy and Power Engineering, Tomsk Polytechnic University, Tomsk 634050, Russia; \\ norrischakovich@mail.ru \\ * Correspondence: firedanger@yandex.ru
}

Received: 5 April 2020; Accepted: 6 July 2020; Published: 7 July 2020

\begin{abstract}
The present work is devoted to the theoretical study of heat transfer in the enclosing structures of a wooden building exposed to the front of a forest fire. In the general case, the following effects could be distinguished: The direct effect of a forest fire flame, the effect of convective and radiant heat flux, and the removal of firebrands from the front of a forest fire. In this paper, only building enclosures were considered to be exposed to radiant heat flux from the front of a forest fire. The scenarios of the impacts of low- and high-intensity surface forest fires and crown forest fires were considered, taking into account the parameterized structure of the fire front, as well as various cladding materials and the time of the forest fire. As a result of mathematical modeling, temperature distributions over the surface and thickness of the cladding material were obtained, and ignition conditions were determined based on experimental data. The proposed simplified mathematical model and the obtained results can be used in the practice of protecting industrial facilities or rural settlements from forest fires. Particular attention should be paid to the potential use of the results in the Information System for Remote Monitoring of Forest Fires, ISDM-Rosleskhoz, in conjunction with geo-information technologies and methods of remote monitoring.
\end{abstract}

Keywords: mathematical simulation; forest fire; wood; building; impact; thermal radiation

\section{Introduction}

Forest fires are a catastrophic phenomenon that causes ecological, economic, and social damage [1]. The first is expressed in the amount of damaged or dead commercial timber, as well as in damage from the destruction or damage of rural settlements or industrial objects, which has taken place in the last decade [2]. Societal damage is expressed in the number of people injured or dead in forest fires. In Wildland-Urban Interface (WUI) zones, residential buildings can be involved in combustion processes [3]. The main impact of a forest fire is directed on the enclosing structures of a residential or industrial building. The main mechanism of heat transfer in this case is radiant heat transfer [4]. Conducting large-scale experiments is either prohibited or difficult due to the inability to control all of the parameters of the process [5]. To date, a sufficient number of software development and computing systems have been created; for example, Microsoft Visual Studio, RAS Studio, Matlab, and ANSYS [6-9]. Such systems can be used to develop computing programs that simulate the heat transfer process in the enclosing structures of a residential or industrial building.

The use of computer systems will eliminate the possibility of dangerous and expensive experiments on the effects of forest fires on residential and other buildings in a rural community or industrial facilities. In addition, it is possible to carry out scenario modeling to assess the consequences of various options for the impact of a forest fire on residential and other buildings.

Forest fires are of various types, namely low- and high-intensity surface forest fires and crown forest fires. Each forest fire is characterized by the height of the flame front, the speed of propagation, and the 
distance to an industrial facility or rural settlement. The average propagation speeds include [10]: Surface forest fire of low intensity $-0.015 \mathrm{~m} / \mathrm{s}$; surface forest fire of high intensity $-0.05 \mathrm{~m} / \mathrm{s}$; crown forest fire $-0.33 \mathrm{~m} / \mathrm{s}$. The front of the fire, as a rule, has an elongated ovoid shape. Residential buildings or auxiliary premises of an industrial facility can have various characteristics, including building material, cladding material, and surface painting in various colors [11].

This work is aimed at studying the effects of forest fires on buildings in forests near Lake Baikal (Republic of Buryatia, Russian Federation) [12]. Forests of the Baikal Territory have recreational and tourist significance, and for this reason, campsites are also located on this territory. The buildings of such campsites are also made of wood and wood-glued materials. It is important to understand how a forest fire affects such buildings in order to be able to assess their fire safety.

Studying the fire safety of such buildings is important. On the one hand, campsites are sources of anthropogenic pressure on forested areas [13]. On the other hand, forest fires can threaten the normal functioning of industrial facilities and campsites in this wooded area.

The purpose of this study is the mathematical modeling of heat transfer processes in the building enclosures of a wooden building when exposed to radiation from the front of a forest fire, taking into account the characteristics of building materials and the characteristics of a forest fire for sustainable functioning and development of rural settlements, industrial facilities, and recreational areas within WUI zones.

\section{Background}

A huge number of both individual residential buildings and entire settlements are affected by forest fires every year, especially in areas where buildings are integrated into the forest [14]. Over the past ten years, forests have continued to be intensively developed with buildings for various purposes, and in the future, this area will increase [15,16]. For these regions, a significant hazard is the risk of a forest fire, which can be caused by both natural and man-made factors [17,18].

In order to start discussing measures to reduce the risk of forest fire exposure through control of forest fuel, it is useful to classify land into three zones [19]:

1. Wildlife areas that are inaccessible to humans; as a result, the risk of fire for man-made reasons is minimal. Monitoring the state of forest fuel can be applicable as a part of preventive measurements against forest fires. Such measures can help to manage forest fire danger situations and reduce fire severity in the future.

2. The main areas of forest management, including more accessible areas of forest, as well as areas with commercial wood.

3. Residential areas; these are plots where the borders of houses are in contact with the borders of the forest. Often, control over forest fuel is aimed at protecting places of mass settlements and infrastructure.

The second and third zones can be further conditionally divided into three risk-reduction groups [20]:

- Single units and adjoining surroundings.

- Borders between settlements and wild vegetation.

- Wild vegetation between settlements.

The need to prepare for forest fires has led to the fact that, over the past 30 years, computer technologies have been introduced into the processes of modeling fire behavior [21], determining the locations and states of accumulation of forest fuels [22,23], and creating complex risk maps for forest fires in large areas [24,25].

Such advancements in the field of cartography were realized to a large extent due to various geospatial technologies, including geographic information systems (GIS) and remote sensing. 
These technologies make it possible to conduct an economic assessment of various landscape features without lengthy expeditions to the study area [26].

Although the cost and risk of fires at WUIs increased significantly $[27,28]$, no tools were developed to solve the problem of the occurrence of these fires [29]. When modeling fires, the researcher encounters the problem that the length and time frame associated with wildfires and fires in the WUIs are in a wide range of values, ranging from millimeters and tenths of a second to tens of kilometers and days [30].

Recently, work in the field of modeling the effects of flames on wooden structures has been gradually moving from probabilistic to deterministic modeling. In this case, modeling of structural elements of buildings is possible.

So, for example, in [31], a numerical simulation of the keyed connection was performed; the obtained results were in good agreement with the previously obtained experimental data. This fact indicated that the component model can simulate wood compounds under fire exposure with high accuracy. In [32], a wooden joint of two beams was modeled-a dovetail joint. The finite element method was chosen as the research method; modeling took place in the ANSYS software environment. The results obtained were in good agreement with the previously obtained experimental data. A criterion known as Tsai-Wu, which, at room temperature, is useful for modeling and predicting failure times, is useless with a burning time of more than $30 \mathrm{~min}$.

Reference [33] is devoted to the creation of a mathematical model of the structural behavior of wooden columns in a fire to assess the bearing capacity of wooden columns. Particular attention was paid to critical bending loads. The dependences of the effect of the coefficient of elasticity, load level, and water content on critical bending loads were obtained. Prior to this, full-scale firing tests of the columns $[34,35]$ were carried out; however, they had a number of drawbacks, such as the high cost, reproducibility, and reliability of the results described in [36]. Therefore, in this field of research, analytical, numerical, semi-empirical, and empirical methods are actively developing.

The rapidly deployable instrumentation packages described in [37] proved to be suitable for measuring environmental characteristics, such as air temperature, wind direction and speed, and relative air humidity near the structure, as well as for representing the ignition structure. Directional Flame Thermometers (DFTs) were acceptable for measuring total heat flux.

However, probabilistic models continue to evolve, supplemented by new dependencies. In [38], a fire propagation model was built inside a building based on a Bayesian network with a known fire source, as well as the probability of flame propagation using the joint probability distribution of the Bayesian network.

Experimental studies of failure times for various floor materials were presented in [39]. In this work, several floor systems were studied for real fire scenarios. The data obtained can be used in dynamic risk assessment systems that will help fire departments in fighting fires.

An experimental study of combustion of transversely laminated wooden structures presented in [40] showed the influence of the properties of the glue used for gluing wooden structures. Depending on the properties of the adhesive, the roll-off of parts of a burning layered structure leads to an increase in the carbonization rate in comparison with a homogeneous wooden structure. In cases when the burning layers did not fall off, the behavior of fire was similar to that of fire when burning homogeneous wooden structures.

In [41], an experimental study of flame propagation in an urban environment was conducted. This work was carried out to obtain data on the height of the flame after burning the roof of a wooden building for computational models. A conversion factor was introduced into one of the standard flame height models, taking into account fresh air inflows through leaks of building structures due to pressure differences inside and outside the building. This model reflects a general change in flame height as a function of time, with quantitative agreement being unsatisfactory.

In [42], experiments were carried out to measure the time of uncontrolled ignition, the incident heat flux, and the temperature of a rear surface of spruce. The data were obtained in combination with a numerical model of heat transfer to determine the unsteady temperature distribution in each 
sample when the surface temperature reached a critical value sufficient for ignition. The ignition models proposed in $[43,44]$ were further generalized models to predict the ignition of solids at an experimentally determined minimum incident heat flux $[45,46]$.

The work of [47] presents the EcoSmart Fire software, which is designed to simulate the ignition of buildings in WUI zones. The software allows the user to simulate the pilot ignition of buildings as a result of exposure to radiation heat flux. The program predicts the building's ignition from a cylindrical forest fire, which can affect walls and roofs. It should be noted that the use of foreign software may be prohibited on the territory of the Russian Federation in accordance with the legislation of the country regarding security issues. It is necessary to develop our own software for assessing the fire safety of industrial facilities and rural settlements.

The work of [48] describes the procedure for modeling heat transfer in cross-laminated timber panels that are exposed to fire. The procedure was implemented in Abaqus software [49]. For modeling, the finite element method was used.

In Reference [50], a joint model of heat and mass transfer was used to analyze the process of heat exposure to wood in the temperature range of $200-260{ }^{\circ} \mathrm{C}$. A rather complex mathematical model was considered that takes into account the multi-stage pyrolysis process. First, the thermal decomposition of wood into char, tar, and gases was considered. In the second stage, the tar decomposes into char and gases. Separately, the components of wood were considered: Hemicellulose, cellulose, and lignin.

In [51], a three-dimensional non-stationary mathematical model was considered, which was used to model the effect of high temperature on wood. The model is based on Luikov's approach. As a result of numerical implementation, heat and mass transfer equations were jointly solved. Using this mathematical model, temperature and moisture content curves of wood were obtained as a function of time.

In [52], a model of oxidative pyrolysis of wood was considered. A generalized pyrolysis model (Gpyro) was applied to modeling of the oxidative pyrolysis of wood. A system of equations for calculating temperature, mass fractions, and pressure curves inside decaying wood was solved. The model takes into account four heterogeneous reactions (gas/solid) and two homogeneous reactions (gas/gas). In addition, the diffusion of oxygen from the environment into a decaying solid was modeled. A genetic algorithm was used to extract the necessary data on material properties from experimental data for heat fluxes of 25 and $40 \mathrm{~kW} / \mathrm{m}^{2}$ and oxygen concentrations of $0 \%, 10.5 \%$, and $21 \%$ by volume.

\section{Methodology}

As a method for numerically solving the differential heat in Equation (1), the finite difference method was used. This method is described in detail in [53,54].

$$
\rho c \frac{\partial T}{\partial t}=\frac{\partial}{\partial x}\left(\lambda \frac{\partial T}{\partial x}\right)+\frac{\partial}{\partial y}\left(\lambda \frac{\partial T}{\partial y}\right)+\frac{\partial}{\partial z}\left(\lambda \frac{\partial T}{\partial z}\right)+Q_{w}(x, y, z, y, T)
$$

An implicit difference scheme was used for the solution. The left boundary condition was used to determine the running coefficients $\alpha$ and $\beta$ from the relation $T_{1}=\alpha_{1} \cdot T_{2}+\beta_{1}$. The right boundary condition is used to determine the temperature at the boundary $x=L$; for the number of nodes $N$, the temperature at the boundary will have the form $T_{N}(K)$. The boundary conditions were discredited with the first order of accuracy. It is assumed that the front of a forest fire is approaching the structure on the left side. Convection-radiation heat transfer at the boundary of the building enclosure is considered, as is an approximation on the left and right boundaries.

On the left border $x=0$ :

$$
-\left.\lambda_{1} \frac{\partial T}{\partial x}\right|_{x=0}=\alpha\left(T_{f}-T_{1}\right)+\varepsilon \sigma\left(T_{f}^{4}-T_{1}^{4}\right)+q .
$$


Then,

$$
\left\{\begin{array}{c}
\alpha_{1}=\frac{\lambda_{1}}{\lambda_{1}+h \alpha}, \\
\beta_{1}=\frac{h \alpha T_{f}+\varepsilon \sigma h\left(T_{f}^{4}-T_{1}^{4}\right)+h q}{\lambda_{1}+h \alpha} .
\end{array}\right.
$$

At the border between the cladding and part of the facade, it is necessary to set the boundary conditions of the fourth kind. The air slot, in the vast majority of cases, does not affect the heat transfer in the cladding material, since it is located outside the range of significant temperature changes in the thickness of the building enclosure. At the layer boundary $x=L_{x}$ (some $i$-th node):

$$
\left\{\begin{array}{l}
\alpha_{i^{*}}=\frac{\lambda_{2}}{\lambda_{2}+\lambda_{1} \cdot\left(1-\alpha_{i^{*}-1}\right)}, \\
\beta_{i^{*}}=\frac{\lambda_{1} \cdot \beta_{i^{*}-1}}{\lambda_{2}+\lambda_{1} \cdot\left(1-\alpha_{i^{*}-1}\right)} .
\end{array}\right.
$$

On the right border, it is necessary to take into account the influence of the internal space on the wall temperature. It will be logical to set the boundary conditions of the third kind, which describe the convective heat transfer of the wall and the inside of the house. At the boundary $x=L$ :

$$
T_{N}=\frac{\lambda_{2} \cdot \beta_{N-1}+h \cdot k \cdot T^{e 2}}{h \cdot k+\lambda_{2}\left(1-\alpha_{N-1}\right)}
$$

It should be noted that, in the left boundary condition, there is a nonlinear term responsible for heating the surface according to the Stefan-Boltzmann law. Therefore, it is necessary to use, for example, the simple iteration method. To solve the difference analogs of three-dimensional differential heat equations, the locally one-dimensional Samarskiy method $[53,54]$ was used-when three blocks are allocated in the algorithm for one-dimensional calculation of temperature according to the corresponding spatial coordinate. A three-dimensional model was used to take into account forest fire properties of the height and width of the front. Figure 1 shows a diagram of the algorithm for the numerical calculation of temperature in a two-layer building enclosure in a three-dimensional setting.

Based on these equations, a software implementation was made in the high-level language Delphi. A total of 100,000 nodes took part in the calculation. This number was chosen to reduce the statistical error, since the first order of accuracy was chosen to discredit the boundary conditions.

The surface temperature obtained when calculating at $10^{7}$ nodes, which amounted to $966.5 \mathrm{~K}$, was taken as a reference value, since with a further increase in the number of nodes, the relative error is less than $0.01 \%$. This value was obtained under conditions of an exposure time of $200 \mathrm{~s}$, an initial distance of $20 \mathrm{~m}$, a front movement speed of $3 \mathrm{~m}$ per minute, and veneered plywood lining.

As can be seen from Table 1, when the number of calculation nodes reaches $10^{5}$, the error is only a fraction of a percent; however, their further increase leads to a significant increase in the duration of the program implementation.

Table 1. Comparison of the temperature values for a different number of nodes on the 1D variant.

\begin{tabular}{cccc}
\hline Number of Nodes $\boldsymbol{N}$ & Surface Temperature $\mathbf{T ( 1 ) ,} \boldsymbol{K}$ & Relative Error $\boldsymbol{\delta}, \boldsymbol{\%}$ & Execution Time, $\mathbf{s}$ \\
\hline $\mathbf{1 0}^{\mathbf{2}}$ & 1262.5 & 42.7 & 0.022 \\
\hline $\mathbf{1 0}^{\mathbf{3}}$ & 990.2 & 3.4 & 0.052 \\
\hline $\mathbf{1 0}^{\mathbf{4}}$ & 968.8 & 0.3 & 0.331 \\
\hline $\mathbf{1 0}^{\mathbf{5}}$ & 966.7 & 0.03 & 3.083 \\
\hline $\mathbf{1 0}^{\mathbf{6}}$ & 966.6 & 0.01 & 30.6 \\
\hline $\mathbf{1 0}^{\mathbf{7}}$ & 966.5 & 0 & 306.6 \\
\hline
\end{tabular}




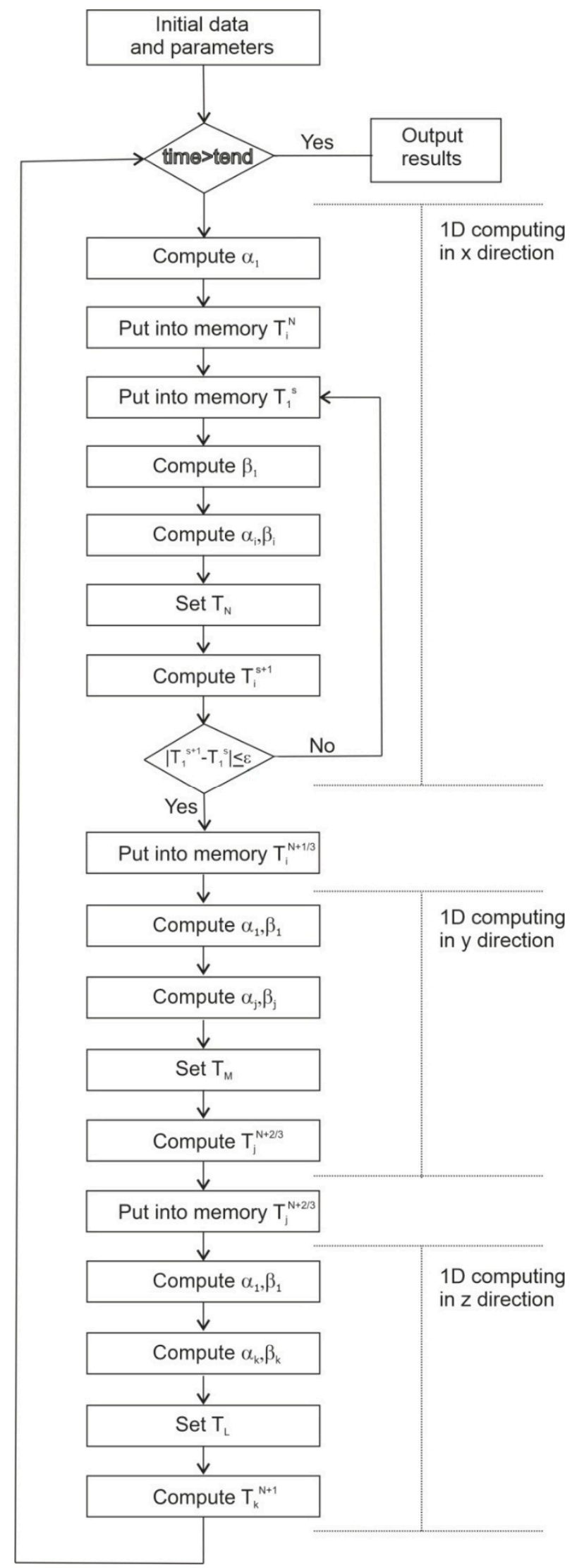

Figure 1. Algorithm of the computational tool. 


\section{Physical and Mathematical Models}

As a physical model, a single-apartment wooden building was taken, located near a forest fire. The front of the fire spreads at a low speed in the absence of wind. The enclosing structures of this building are presented in the form of a two-layer plate. The first layer is cladding, the second is wood. Heat from the front of a forest fire is transmitted to the wall by thermal radiation. The main safety parameter of a wooden structure is the fact of ignition (or non-ignition) of the enclosing structure of the wooden building when a sufficient surface temperature is reached. The following assumptions were made:

- There is a thermal conductivity mechanism in the enclosing structures;

- Three-dimensional setup;

- The fire front's shape is a parabola;

- The thermophysical properties of the building materials do not depend on temperature;

- The paint layer is taken into account using an absorption coefficient; The catastrophic scenario of fire weather is assumed when there is no moisture in the surface layer of the wall;

- Wood pyrolysis is ignored;

- The main heat transfer mechanism from the fire line to the building is thermal radiation;

- The forest fire front's temperature is taken into account using the Stephan-Boltzmann Law;

- The building foundation has a temperature equal to the soil layer's temperature;

- The height of the forest fire front is taken into account on each spatial step from the original distance;

- All cladding materials have their own radiation reflection coefficients;

- The forest fire front's impact on the wall is set by $q_{f f}$ and $T_{f f}$.

The Republic of Buryatia belongs to the third zone of zoning of climatic conditions according to the building rules of the Russian Federation [11]. This is a dry zone. In addition, a catastrophic fire weather scenario is assumed when moisture in the wood is practically absent. These are the most typical conditions for the occurrence of catastrophic forest fires in the Baikal territory [55]. Building rules regulate thermophysical characteristics as independent of temperature. This is an official document that is used in the development of construction documentation for any object in the Russian Federation. In addition, wood moisture significantly affects the values of thermophysical characteristics at a level of $20-30 \%$, and this is no longer a catastrophic scenario for the development of a fire danger situation. Therefore, at this stage of the simulation, the thermophysical characteristics are independent of temperature. The geometry of the decision area is presented in Figure 2.

The mathematical model is described by system of transient heat transfer equations:

$$
\begin{aligned}
& \rho_{1} c_{1} \frac{\partial T_{1}}{\partial t}=\frac{\partial}{\partial x}\left(\lambda_{1} \frac{\partial T_{1}}{\partial x}\right)+\frac{\partial}{\partial y}\left(\lambda_{1} \frac{\partial T_{1}}{\partial y}\right)+\frac{\partial}{\partial z}\left(\lambda_{1} \frac{\partial T_{1}}{\partial z}\right) \\
& \rho_{2} c_{2} \frac{\partial T_{2}}{\partial t}=\frac{\partial}{\partial x}\left(\lambda_{2} \frac{\partial T_{2}}{\partial x}\right)+\frac{\partial}{\partial y}\left(\lambda_{2} \frac{\partial T_{2}}{\partial y}\right)+\frac{\partial}{\partial z}\left(\lambda_{2} \frac{\partial T_{2}}{\partial z}\right) .
\end{aligned}
$$

Initial conditions:

$$
\left.T_{i}\right|_{t=0}=T_{i 0} .
$$

Boundary conditions:

$$
\begin{gathered}
-\left.\lambda_{1} \frac{\partial T_{1}}{\partial x}\right|_{x=0}=k_{1}(1-A) q_{f f}+\varepsilon \sigma\left(T_{f f}^{4}-T_{1}^{4}\right), \\
-\left.\lambda_{1} \frac{\partial T_{1}}{\partial x}\right|_{x=x b}=-\left.\lambda_{2} \frac{\partial T_{2}}{\partial x}\right|_{x=x b}, T_{1}=T_{2}, \\
\left.\lambda_{2} \frac{\partial T_{2}}{\partial x}\right|_{x=H x}=\alpha_{i n}\left(T_{i n}-T_{2}\right),
\end{gathered}
$$




$$
\begin{aligned}
& -\left.\lambda_{1} \frac{\partial T_{1}}{\partial y}\right|_{y=0}=\alpha_{e}\left(T_{e}-T_{1}\right), \\
& -\left.\lambda_{2} \frac{\partial T_{2}}{\partial y}\right|_{y=0}=\alpha_{e}\left(T_{e}-T_{2}\right), \\
& \left.\lambda_{1} \frac{\partial T_{1}}{\partial y}\right|_{y=H y}=\alpha_{e}\left(T_{e}-T_{1}\right), \\
& \left.\lambda_{2} \frac{\partial T_{2}}{\partial y}\right|_{y=H y}=\alpha_{e}\left(T_{e}-T_{2}\right), \\
& -\left.\lambda_{1} \frac{\partial T_{1}}{\partial z}\right|_{z=0}=\alpha_{s}\left(T_{s}-T_{1}\right), \\
& -\left.\lambda_{2} \frac{\partial T_{2}}{\partial z}\right|_{z=0}=\alpha_{s}\left(T_{s}-T_{2}\right), \\
& \left.\lambda_{1} \frac{\partial T_{1}}{\partial z}\right|_{z=H z}=\alpha_{e}\left(T_{e}-T_{1}\right), \\
& \left.\lambda_{2} \frac{\partial T_{2}}{\partial z}\right|_{H z=0}=\alpha_{e}\left(T_{e}-T_{2}\right) .
\end{aligned}
$$

Computational formulae to determine $q_{f f}$ for a surface forest fire's influence on a cladding surface:

$$
q_{f f}=\left(q_{f d}+\frac{x f}{50 d} q_{f h}\right) / 2 .
$$

Computational formulae to determine $q_{f f}$ for a crown forest fire's influence on a cladding surface:

$$
q_{f f}=\left(q_{f d}+\frac{t_{\exp } x f}{10 d} q_{f h}\right) / 2 .
$$

These equations were obtained as a result of data processing on incident heat flux from the forest fire studied in [4]. These equations are the best fit for experimental data [4].

Part of the computation to determine heat flux depends on the distance to the forest fire [4]:

$$
q_{f d}=1000 \cdot 326.37 \exp (-0.2791 x f),
$$

and part of the computation to determine heat flux depends on the height of the forest fire [4]:

$$
q_{f h}=1000 \cdot(16.636 x f+29.772),
$$

where $T_{i}, \rho_{i}, c_{i}$, and $\lambda_{i}$-temperature, density, heat capacity, and thermal conductivity of the material ( $i=1$-cladding; $i=2$-wall material); $\alpha$-heat transfer coefficient (in-indoor environment, $e$-environment, $s$-soil layer); $k_{1}$-heat loss coefficient; $A$-reflection coefficient of the wall surface; $q_{f f}-$ heat flux from the forest fire front; $T_{f f}-$ forest fire front temperature; $x, y, z$-spatial coordinates; $t$-time; $q_{f d}$ - heat flux depending on the distance to the forest fire; $q_{f h}$-heat flux depending on the height of the forest fire; $d$-initial distance to the forest fire; $x f$ - current distance to the forest fire until the end of the exposure time; $t_{\exp }$-exposure time. 


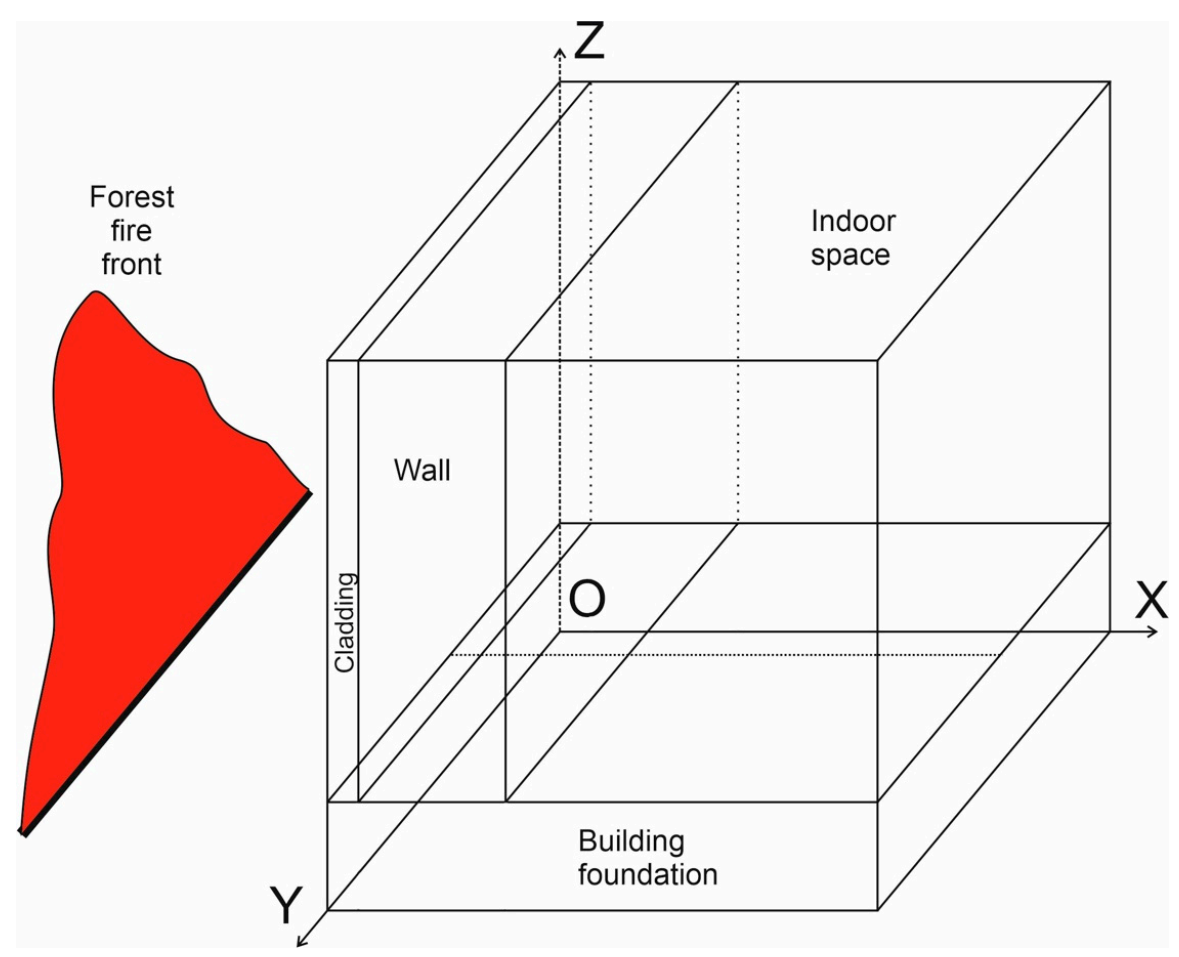

Figure 2. Decision area.

Ignition conditions can be determined using experimental data [56] on the impact of thermal radiation on wood samples (Table 2). In fact, this approach allows us to determine the energy consumption of wood sample until its ignition.

Table 2. Experimental data on wood ignition by thermal radiation [56].

\begin{tabular}{ccc}
\hline Ignition Delay, $\mathbf{s}$ & Heat Flux, $\mathbf{k W} / \mathbf{m}^{\mathbf{2}}$ & Surface Temperature, $\mathbf{K}$ \\
\hline 63.5 & 12.5 & 658 \\
\hline 45.0 & 21 & 700 \\
\hline 11.1 & 42 & 726 \\
\hline 2.6 & 84 & 773 \\
\hline 0.4 & 210 & 867 \\
\hline
\end{tabular}

The thermophysical characteristics of wood and lining materials are presented in Table 3.

Table 3. Thermophysical characteristics of wood [11].

\begin{tabular}{cccc}
\hline Material & $\lambda, \frac{\mathrm{W}}{\mathrm{m} \cdot \mathrm{K}}$ & $c, \frac{\mathrm{J}}{\mathrm{kg} \cdot \mathrm{K}}$ & $\rho, \frac{\mathbf{k g}}{\mathrm{m}^{3}}$ \\
\hline Pine wood & 0.12 & 1670 & 500 \\
\hline Birch wood & 0.28 & 2200 & 650 \\
\hline Glued plywood & 0.12 & 2300 & 600 \\
\hline Facing cardboard & 0.18 & 2300 & 1000 \\
\hline Fiberboard (1000) & 0.15 & 2300 & 1000 \\
\hline Fiberboard (800) & 0.13 & 2300 & 800 \\
\hline Fiberboard (600) & 0.11 & 2300 & 600 \\
\hline
\end{tabular}




\section{Results and Discussion}

In this work, to simulate the radiation effects from the front of a forest fire, numerous scenarios were developed, which are presented in Appendix A. First, three types of forest fires were considered in modeling. The first type is a surface forest fire of low intensity, which is characterized by a flame front height of about $1 \mathrm{~m}$ and a propagation velocity of $0.015 \mathrm{~m} / \mathrm{s}$ across the layer of ground forest fuels. The second type is a surface forest fire of high intensity, which is characterized by a flame height of about $1.5 \mathrm{~m}$ and a propagation velocity of about $0.05 \mathrm{~m} / \mathrm{s}$. In surface forest fires of high intensity, not only a layer of ground forest fuels can burn, but also small shrubs. This leads to a greater speed of its distribution in the forested area. The third type is a crown forest fire, which covers the crowns of trees and moves with a noticeably higher speed than a surface forest fire (about $0.33 \mathrm{~m} / \mathrm{s}$ ). Section 4 presented equations for calculating the magnitude of the radiant heat flux for surface and crown fires. These formulas are a generalization of the results of [4] and allow one to calculate the heat flux from the front of a forest fire of a certain height and at a certain distance from the building enclosures within the limits considered in this article.

The front of the surface forest fire (of low intensity) begins its movement at a distance of $20 \mathrm{~m}$ from the enclosing structure of the wooden building. The wall cladding is made of plywood sheets $(0.02 \mathrm{~m}$ thickness). The second layer is made of pine wood. The fire front speed was set at $0.015 \mathrm{~m} / \mathrm{s}$ and the flame height was set at $1 \mathrm{~m}$. See Figure 3 .

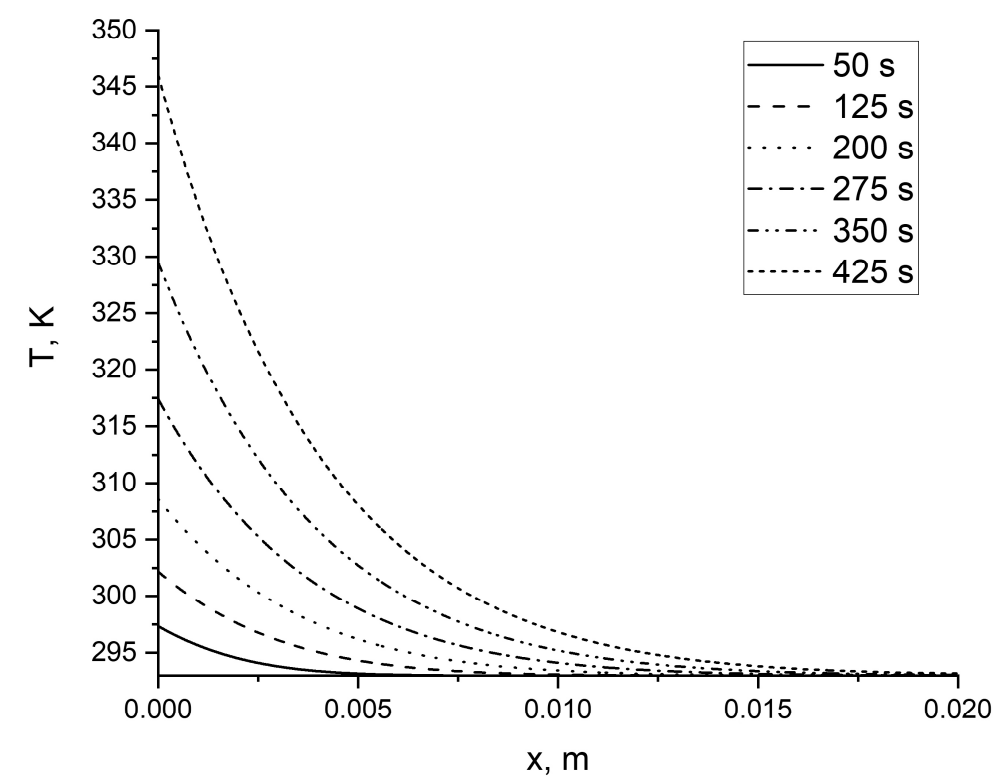

Figure 3. Surface forest fire's (of low intensity) impact on glued plywood from a distance of $20 \mathrm{~m}$ -temperature distribution on wall thickness.

The front of the surface forest fire (of high intensity) begins its movement at a distance of $20 \mathrm{~m}$ from the enclosing structure of the wooden building. The wall cladding is made of plywood sheets $(0.02 \mathrm{~m}$ thickness). The second layer is made of pine wood. The fire front speed was set at $0.05 \mathrm{~m} / \mathrm{s}$ and the flame height was set at $1.5 \mathrm{~m}$. See Figure 4 . 


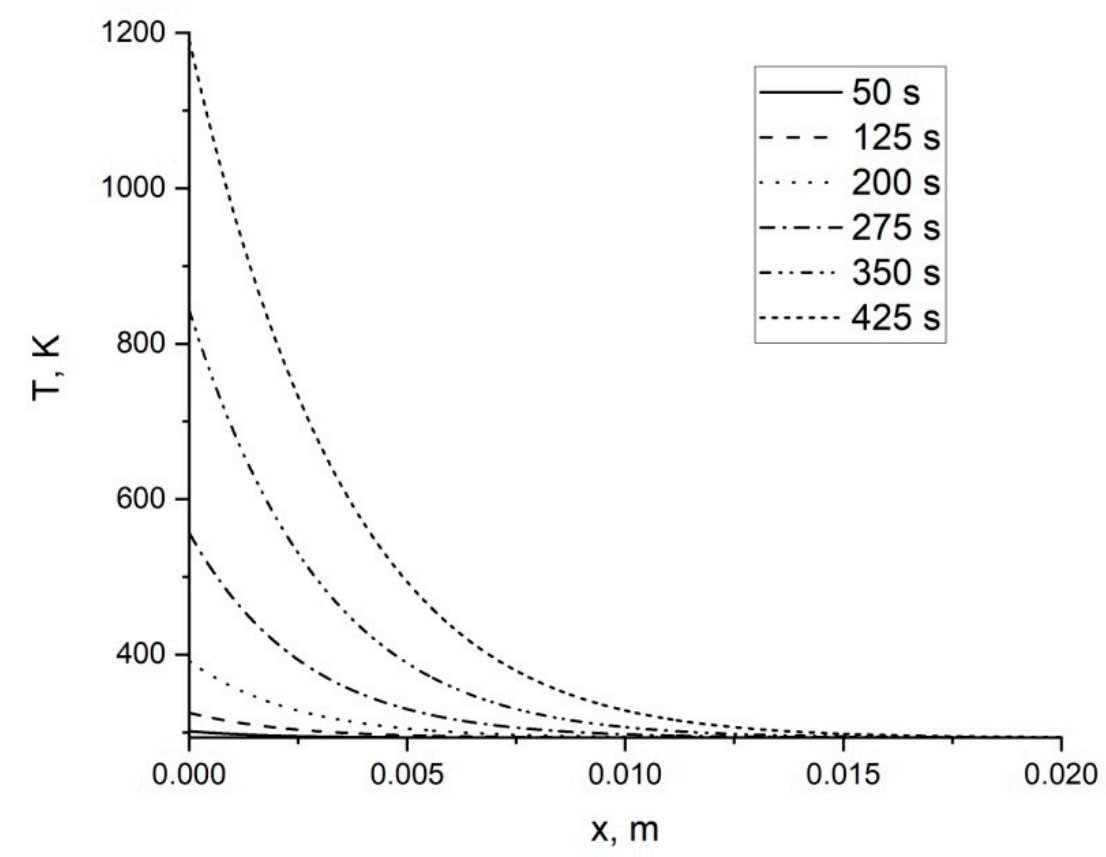

Figure 4. Surface forest fire's (of high intensity) impact on glued plywood from a distance of $20 \mathrm{~m}$ -temperature distribution on wall thickness.

The front of the crown forest fire begins its movement at a distance of $20 \mathrm{~m}$ from the enclosing structure of the wooden building. The wall cladding is made of plywood sheets ( $0.02 \mathrm{~m}$ thickness). The second layer is made of pine wood. The fire front speed was set at $0.33 \mathrm{~m} / \mathrm{s}$ and the exposure time was set to $50 \mathrm{~s}$. See Figure 5.

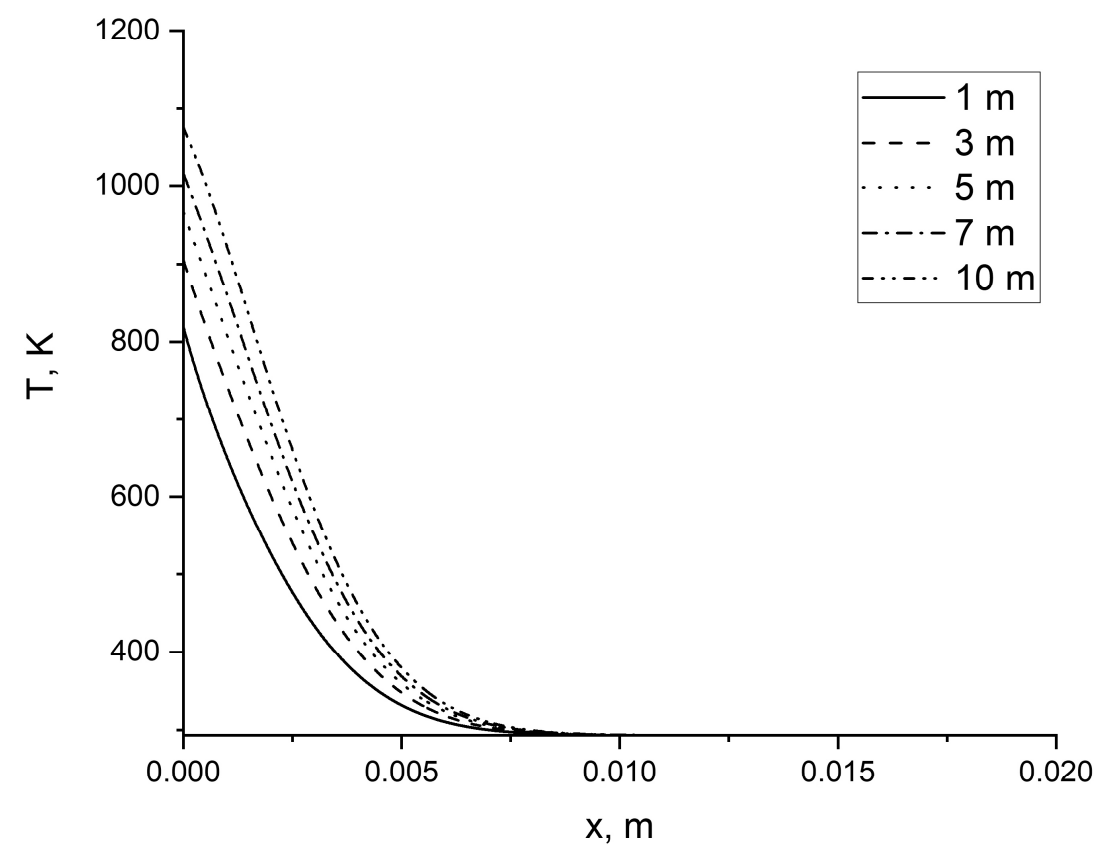

Figure 5. Crown forest fire's impact on glued plywood from a distance of $20 \mathrm{~m}$ for different front heights (from 1 to $10 \mathrm{~m}$ ).

The front of the surface forest fire (of low intensity) begins its movement at a distance of $20 \mathrm{~m}$ from the enclosing structure of the wooden building. The wall cladding is made of plywood sheets $(0.02 \mathrm{~m}$ thickness). The second layer is made of pine wood. The fire front speed was set at $0.015 \mathrm{~m} / \mathrm{s}$ and the flame height was set at $1 \mathrm{~m}$ from 50 to $425 \mathrm{~s}$. See Figure 6. 


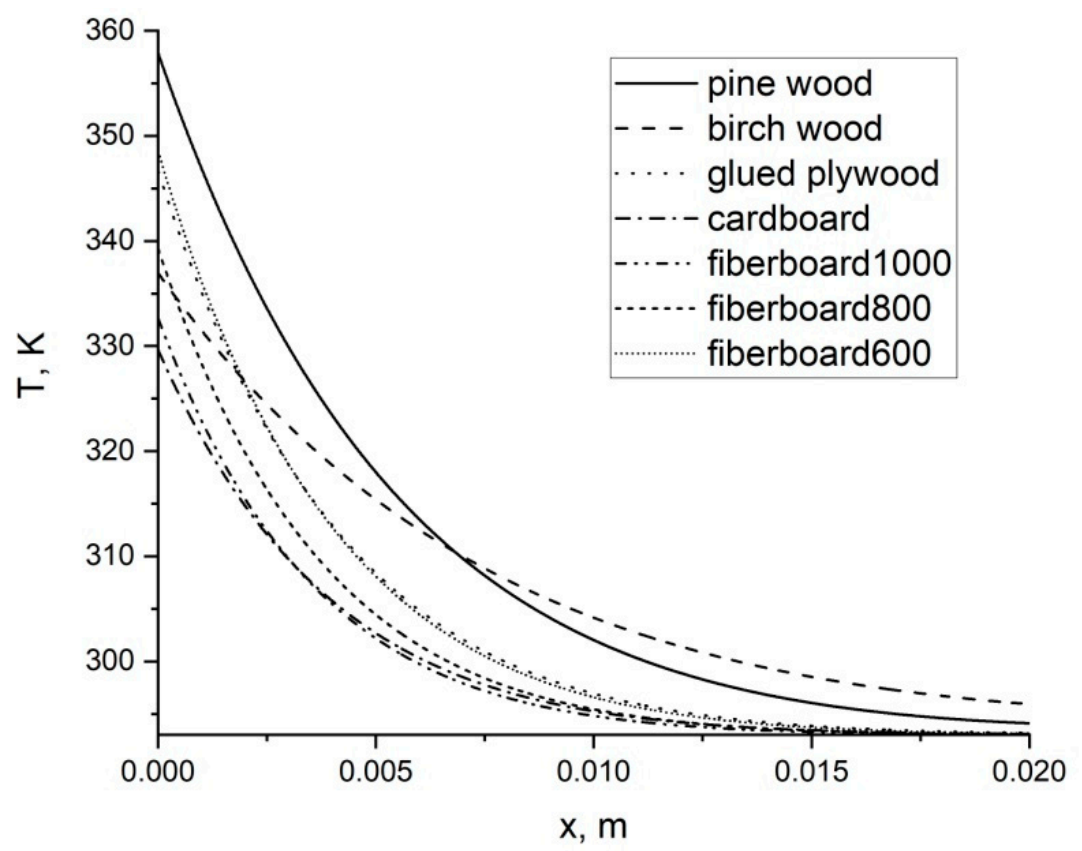

Figure 6. Surface forest fire's (of low intensity) impact on different materials from a distance of $20 \mathrm{~m}$ for $425 \mathrm{~s}$ of exposure-temperature distribution on wall thickness.

The front of the surface forest fire (of high intensity) begins its movement at a distance of $20 \mathrm{~m}$ from the enclosing structure of the wooden building. The wall cladding is made of plywood sheets $(0.02 \mathrm{~m}$ thickness). The second layer is made of pine wood. The fire front speed was set at $0.015 \mathrm{~m} / \mathrm{s}$ and the flame height was set at $1 \mathrm{~m}$ from 50 to $425 \mathrm{~s}$. See Figure 7.

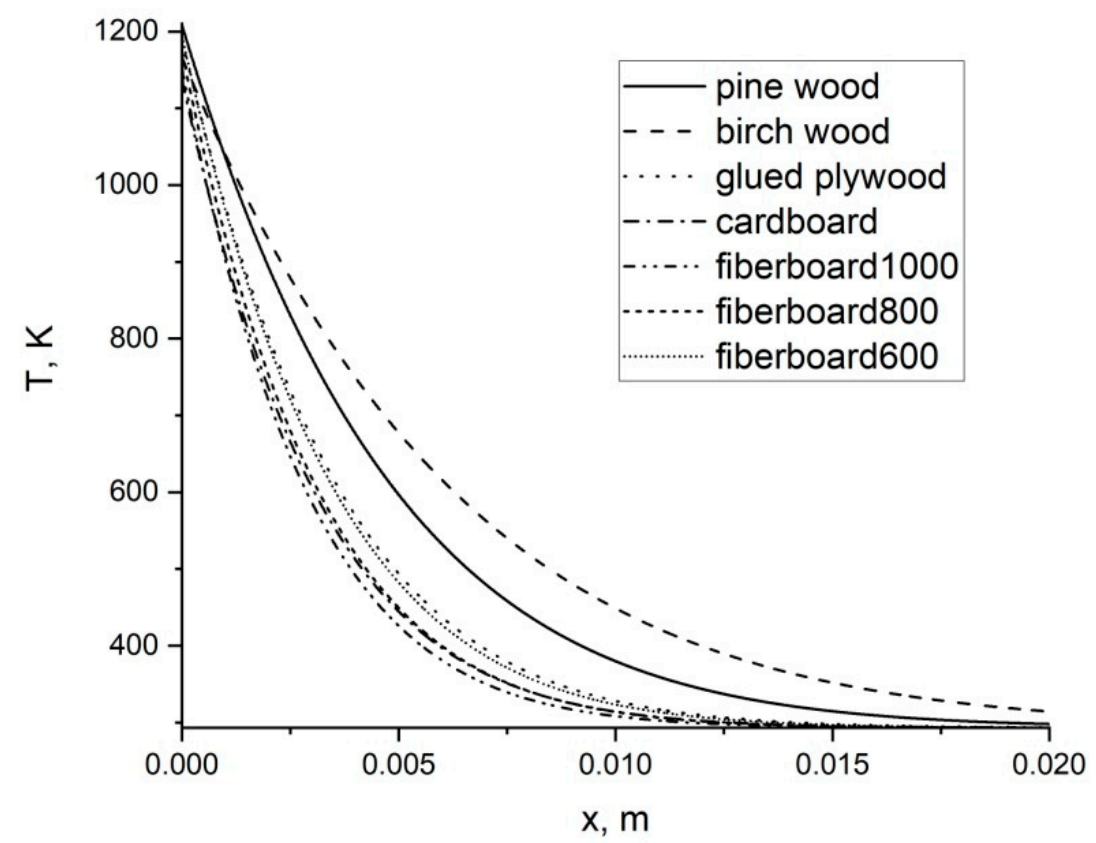

Figure 7. Surface forest fire's (of high intensity) impact on different materials from a distance of $20 \mathrm{~m}$ for $425 \mathrm{~s}$ of exposure-temperature distribution on wall thickness.

Table 4 shows the data on the absorption coefficients of radiant energy for various paints used in civil and industrial construction. According to the building rules [11], data are given on unpainted 
wood, dark gray paint, white and blue paint, and on a surface painted in straw color. For definiteness, glued plywood cladding material is considered.

Table 4. Absorption coefficients for different paints [11].

\begin{tabular}{cc}
\hline Surface Layer of Cladding & Absorption Coefficient \\
\hline Wood without paint & 0.6 \\
\hline Dark gray paint & 0.7 \\
\hline White paint & 0.3 \\
\hline Blue paint & 0.6 \\
\hline Straw-colored paint & 0.45 \\
\hline
\end{tabular}

The front of the surface forest fire (of low intensity) begins its movement at a distance of $20 \mathrm{~m}$ from the enclosing structure of the wooden building. The wall cladding is made of plywood sheets (0.02 $\mathrm{m}$ thickness) with different paints (Table 4). The second layer is made of pine wood. The fire front speed was set at $0.015 \mathrm{~m} / \mathrm{s}$ and the flame height was set at $1 \mathrm{~m}$ for $425 \mathrm{~s}$. See Figure 8 .

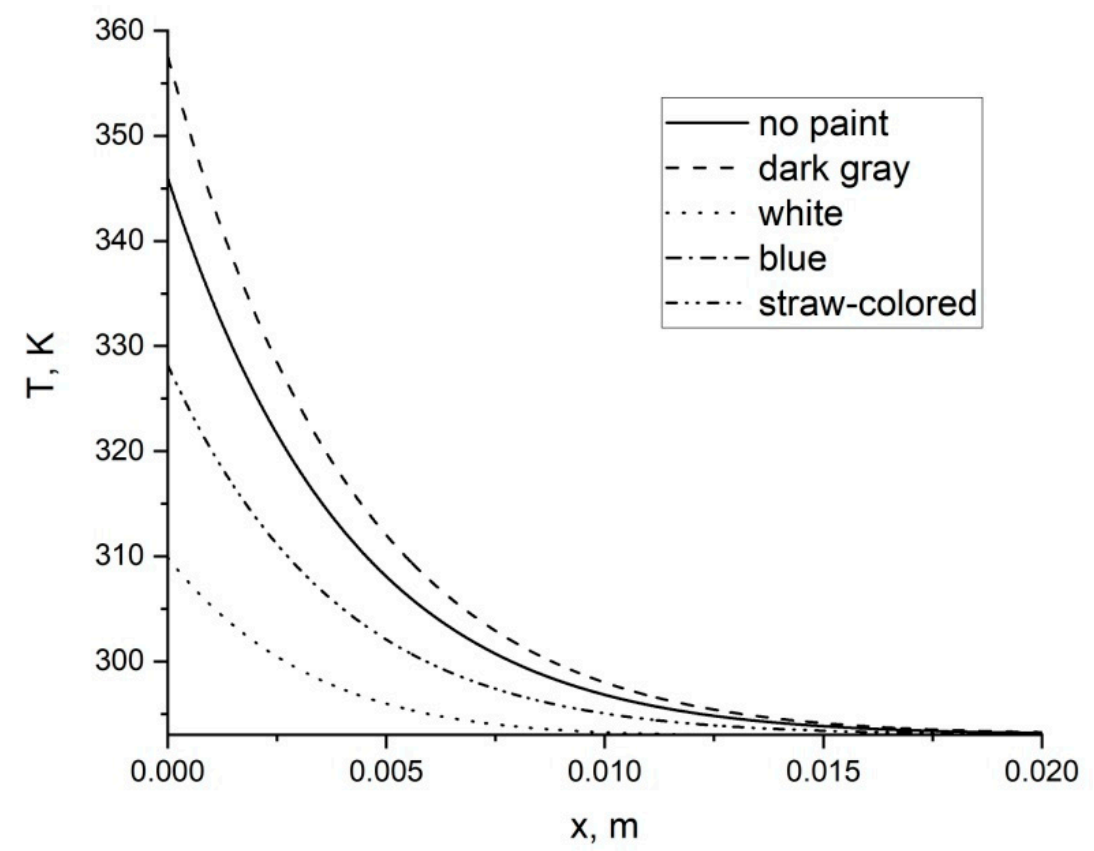

Figure 8. Surface forest fire's (of low intensity) impact on different paints from a distance of $20 \mathrm{~m}$ for $425 \mathrm{~s}$ of exposure-temperature distribution on wall thickness.

The front of the surface forest fire (of high intensity) begins its movement at a distance of $20 \mathrm{~m}$ from the enclosing structure of the wooden building. The wall cladding is made of plywood sheets (0.02 $\mathrm{m}$ thickness) with different paints (Table 1$)$. The second layer is made of pine wood. The fire front speed was set at $0.05 \mathrm{~m} / \mathrm{s}$ and the flame height was set at $1 \mathrm{~m}$ for $425 \mathrm{~s}$. See Figure 9 . 


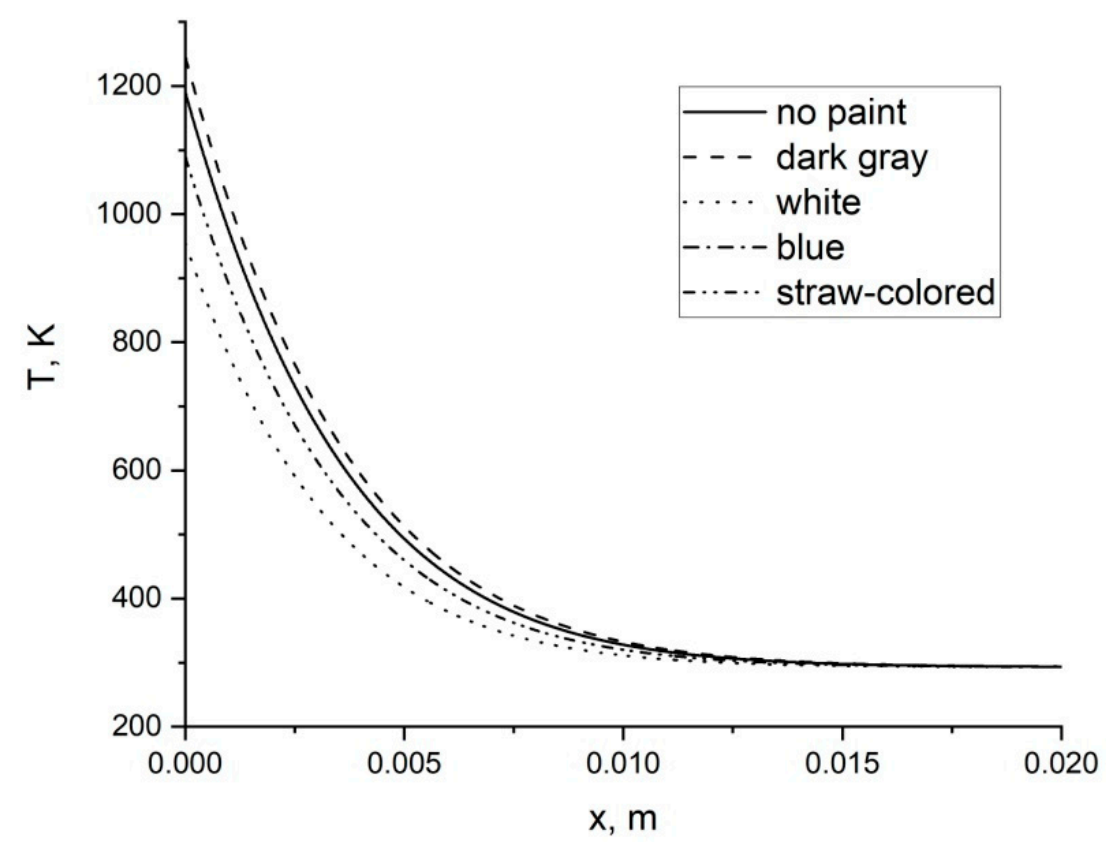

Figure 9. Surface forest fire's (of high intensity) impact on different paints from a distance of $20 \mathrm{~m}$ for $425 \mathrm{~s}$ of exposure-temperature distribution on wall thickness.

The front of the crown forest fire (on $1 \mathrm{~m}$ height) begins its movement at a distance of $20 \mathrm{~m}$ from the enclosing structure of the wooden building. The wall cladding is made of plywood sheets $(0.02 \mathrm{~m}$ thickness) with different paints (Table 4). The second layer is made of pine wood. The fire front speed was set at $0.33 \mathrm{~m} / \mathrm{s}$ and the flame height was set at $1 \mathrm{~m}$ for $50 \mathrm{~s}$. See Figure 10 .

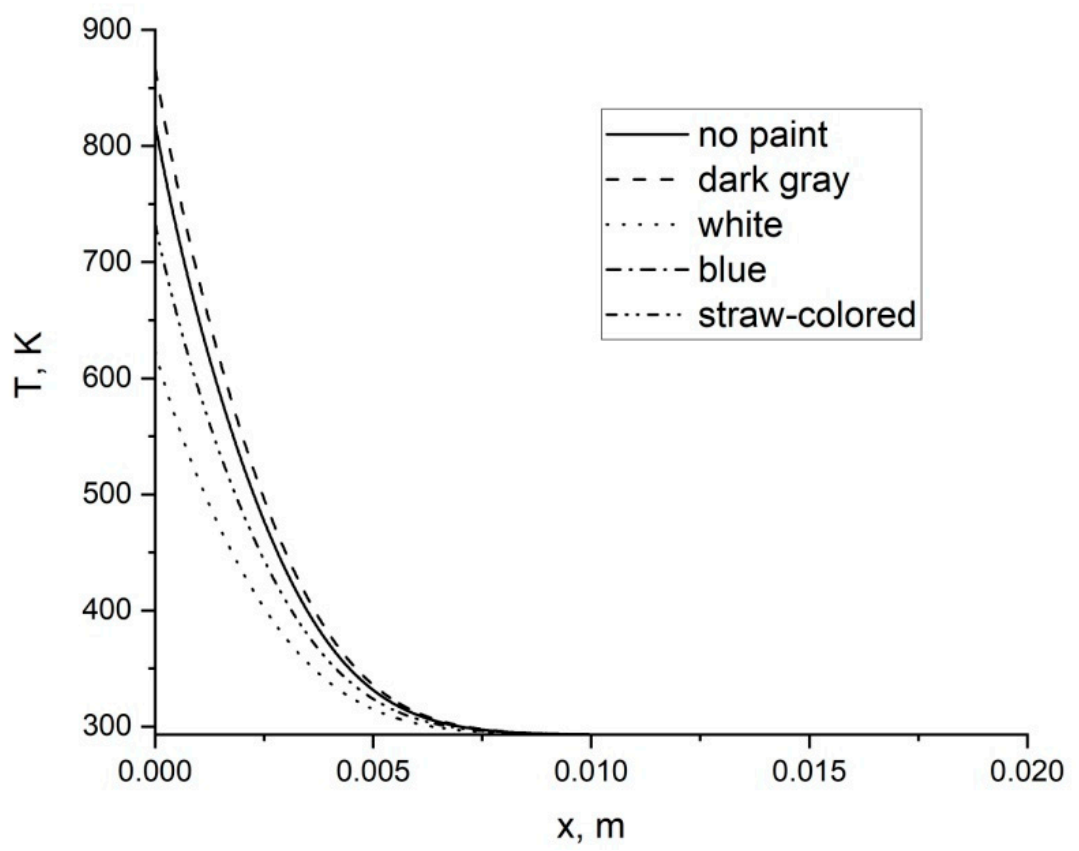

Figure 10. Crown forest fire's (with $1 \mathrm{~m}$ height) impact on different paints from a distance of $20 \mathrm{~m}$ for $50 \mathrm{~s}$ of exposure-temperature distribution on wall thickness.

The front of the crown forest fire (on $5 \mathrm{~m}$ height) begins its movement at a distance of $20 \mathrm{~m}$ from the enclosing structure of the wooden building. The wall cladding is made of plywood sheets $(0.02 \mathrm{~m}$ thickness) with different paints (Table 4). The second layer is made of pine wood. The fire front speed was set at $0.33 \mathrm{~m} / \mathrm{s}$ and the flame height was set at $1 \mathrm{~m}$ for $50 \mathrm{~s}$. See Figure 11. 


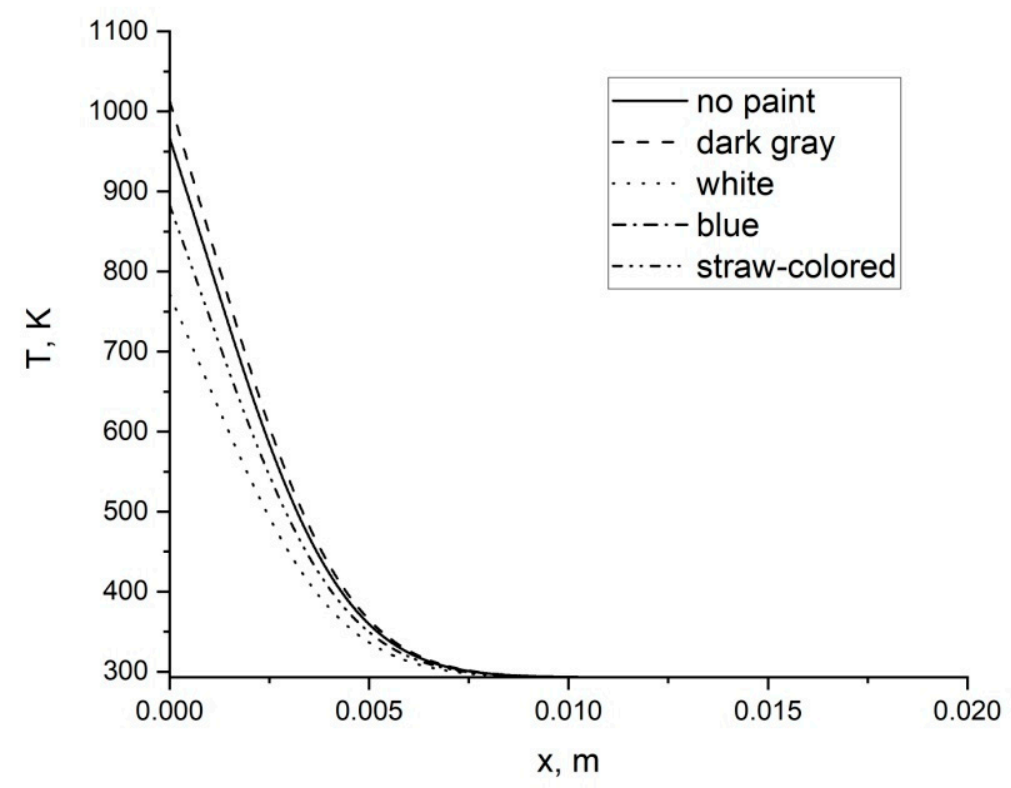

Figure 11. Crown forest fire's (with $5 \mathrm{~m}$ height) impact on different paints from a distance of $20 \mathrm{~m}$ for $50 \mathrm{~s}$ of exposure-temperature distribution on wall thickness.

The front of the crown forest fire begins its movement at a distance of $20 \mathrm{~m}$ from the enclosing structure of the wooden building. The wall cladding is made of different materials $(0.02 \mathrm{~m}$ thickness $)$ without paint. The second layer is made of pine wood. The fire front speed was set at $0.33 \mathrm{~m} / \mathrm{s}$ and the flame height was up to $10 \mathrm{~m}$ for $50 \mathrm{~s}$. See Figure 12.

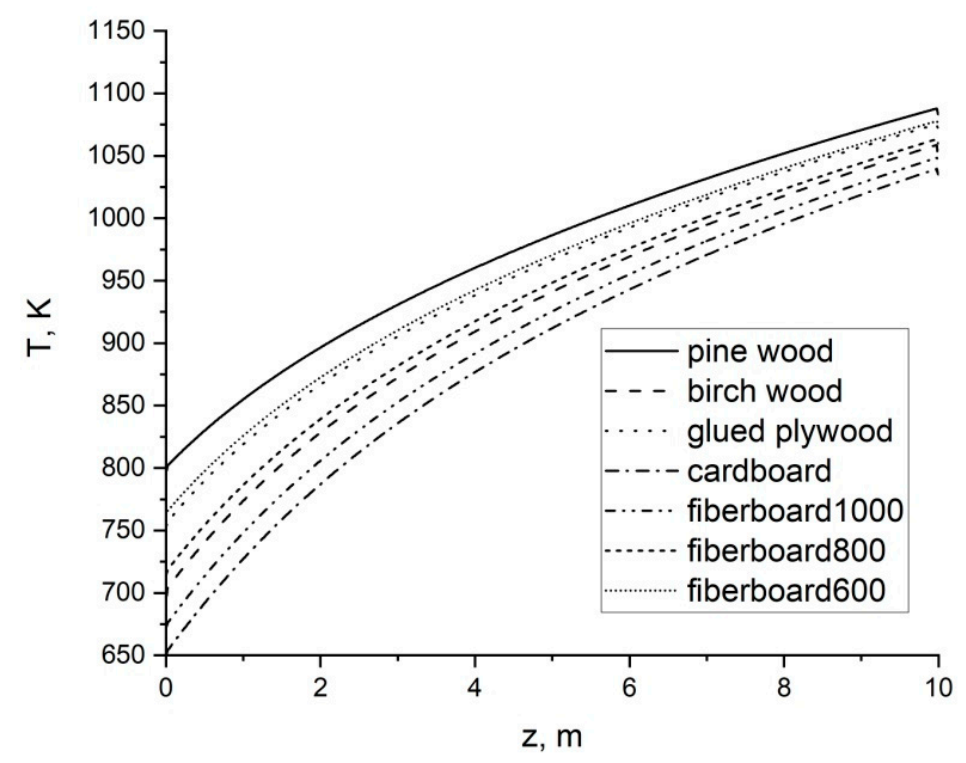

Figure 12. Crown forest fire's (up to $10 \mathrm{~m}$ height) impact on different materials from a distance of $20 \mathrm{~m}$ for $50 \mathrm{~s}$ of exposure (surface temperature)—-temperature distribution on wall height.

The front of the surface forest fire (of low intensity) begins its movement at a distance of $20 \mathrm{~m}$ from the enclosing structure of the wooden building. The wall cladding is made of different materials (0.02 $\mathrm{m}$ thickness) without paint. The second layer is made of pine wood. The fire front speed was set at $0.015 \mathrm{~m} / \mathrm{s}$ and the fire front shape was parabolic over $425 \mathrm{~s}$. See Figure 13. 


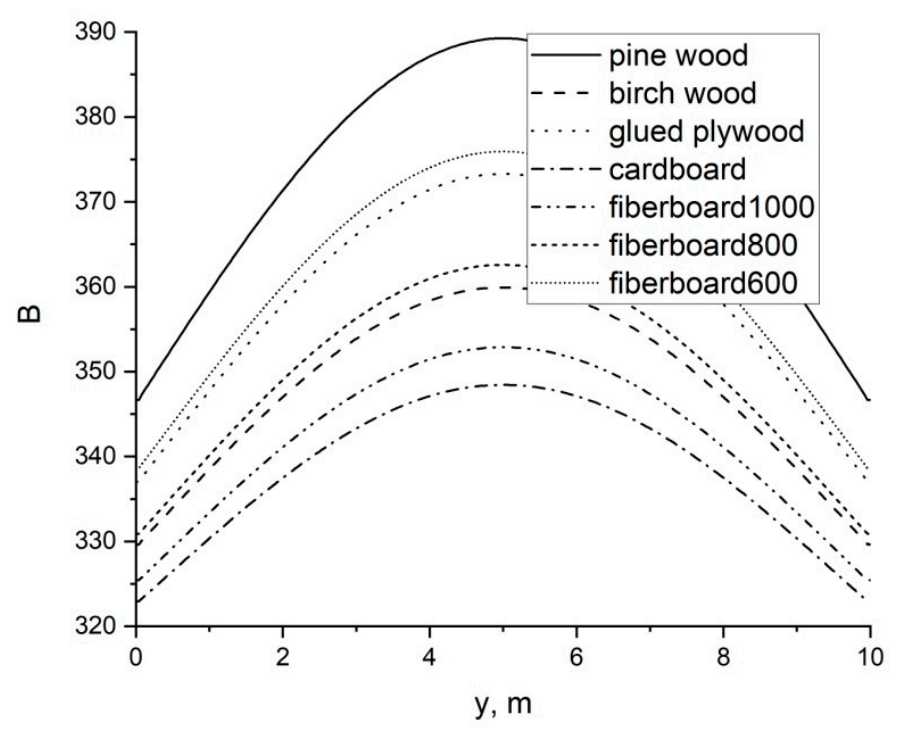

Figure 13. Surface forest fire's (of low intensity) impact on different materials from a distance of $20 \mathrm{~m}$ for $425 \mathrm{~s}$ of exposure with a parabolic shape-temperature distribution on wall width.

The front of the surface forest fire (of high intensity) begins its movement at a distance of $20 \mathrm{~m}$ from the enclosing structure of the wooden building. The wall cladding is made of different materials ( $0.02 \mathrm{~m}$ thickness) without paint. The second layer is made of pine wood. The fire front speed was set at $0.015 \mathrm{~m} / \mathrm{s}$ and the fire front shape was parabolic over $425 \mathrm{~s}$. See Figure 14.

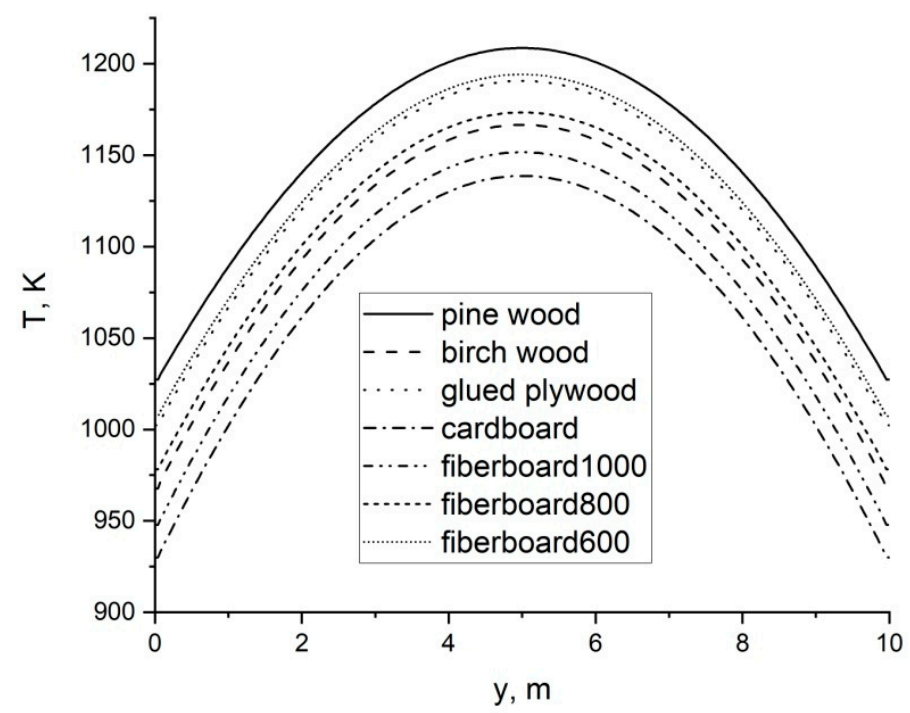

Figure 14. Surface forest fire's (of high intensity) impact on different materials from a distance of $20 \mathrm{~m}$ for $425 \mathrm{~s}$ of exposure with a parabolic shape-temperature distribution on wall width.

As a result of numerous computational experiments, the following patterns of the effects of forest fires on the enclosing structures of a wooden building were obtained.

The first group of computational experiments examined the effects of various forest fires on a wall lined with various types of cladding. As was established as a result of modeling, the wall is heated mainly at the stage preceding ignition, and the heating occurs in the surface layers of the cladding with a thickness of about $2 \mathrm{~cm}$. Unpainted wood-glued materials are considered.

In the case of a low-intensity surface forest fire that began to move from a distance of $20 \mathrm{~m}$, the temperature distributions shown in Figure 3 were obtained over the thickness of the building enclosure. 
At this distance, the fire does not have a noticeable effect on the building enclosure of a wooden building, since its speed of propagation is small. A fire has a real impact when its front approaches a distance of about two meters.

When a surface forest fire of high intensity is considered, there is a noticeable effect when moving the fire front from a distance of $20 \mathrm{~m}$ over a propagation period of $275-350 \mathrm{~s}$. In this case, the surface temperature rises above $500 \mathrm{~K}$, when the processes of thermal decomposition of wood already occur [56]. In fact, the owners of the dwelling or the workers of the industrial facility do not have time to remove the ground layer of forest fuels and shrubs near the building. Likewise, there is no time for forced wetting of the walls of the building in order to reduce the effects of fire on the building. The only solution is the early removal of shrubs and the organization of mineralized strips [57] at a certain distance (more than $2 \mathrm{~m}$ ) from the building enclosure. Otherwise, the front of the forest fire will reach a distance at which ignition of the enclosing structures of a residential or industrial building is possible.

For a crown forest fire, one minute is enough to reach a critical distance from the enclosing structures of a residential or industrial wooden building. Moreover, in the entire range from 1 to $10 \mathrm{~m}$, fire-hazardous temperatures are reached on the surface of the building enclosure. No operational measures will save the owners of the dwelling or the workers of an industrial facility in the event of a forest fire's approach. The only solution is the thinning of the forest around the buildings so that there are large distances between the crowns of the trees. Only this can ensure the absence of the transition of the flame front from one tree to another. The installation of elements of computerized visual control of forest fires of the Lesnoy Dozor software-hardware complex [58] in a forest stand is an option. Such a system should automatically recognize a forest fire at a considerable distance from an industrial facility or rural settlement and notify owners or workers of the approach of a crown forest fire. In this case, owners or workers can leave the building and evacuate to a safe distance. A prerequisite for minimizing damage to the owners of the building is their agreement with an insurance company [59].

Figure 6 shows the temperature curves in cladding layers of various types for the approaching front of a surface forest fire of low intensity with an exposure time of $425 \mathrm{~s}$. As can be seen from Figure 6, the maximum heating is characteristic of pure pine material, which is not covered with any cladding materials. Most notably, fire risk is reduced by cardboard and fiberboard cladding with a density of $1000 \mathrm{~kg} / \mathrm{m}^{3}$. Other materials are intermediate in the figure. In general, the effect of a surface forest fire of low intensity over a given period of time does not constitute a danger to any cladding materials. The owner of a dwelling or an employee of an industrial facility has a certain amount of time, for example, to moisten the wall of the building or to use a backpack sprayer to extinguish the edge of a surface forest fire. Alternatively, the owner or worker may try to make a mineralized strip with a cultivator at some distance from the building to prevent the further spread of the front of a surface forest fire.

Figure 7 shows the temperature distribution over the thickness of the enclosing structure of a wooden building for various cladding materials in the event of exposure to a surface forest fire of high intensity for an exposure time of $425 \mathrm{~s}$. As the analysis of the results shown in Figure 7 shows, the temperature of the surface layer is above critical for any type of cladding material. Moreover, the cladding layer is heated to a depth of $1 \mathrm{~cm}$. The difference in the temperature of the surface and the surface layer of 10-100 K does not matter. All types of cladding are dangerous. It must be assumed that, in this case, the owner of the building can only use advance measures to minimize damage-namely, removing shrubs and laying mineralized strips at a certain distance from the building. Alternatively, one must leave the building to avoid injuries, burns, and death $[60,61]$.

The figure demonstrating the effect of the crown forest fire is not presented, since, in the event of the development of such a forest fire in the vicinity of the wooden building, the owner can be saved only by early thinning of the forest and rapid evacuation from the place of residence. Any cladding materials are extremely dangerous with respect to fire.

Figure 8 presents the results of modeling the impact of a surface forest fire of low intensity. In this case, the building can be painted in any color, since the mineralized strip is enough to prevent the 
forest fire from transitioning to the building. A comparative analysis shows that a surface painted white is the least susceptible to heat. Moreover, the difference in surface temperature is about $50 \mathrm{~K}$ between the painting in white or dark gray.

In the case of a surface forest fire of high intensity, only coloring the surface in white gives some advantage. During the exposure of $425 \mathrm{~s}$, the front of a surface forest fire of high intensity approaches almost close to the enclosing structures of a wooden building, and its ignition is possible with any color scheme. However, painting the surface of the enclosing structure in white gives some chance of postponing the ignition time in the case of using forced wetting of the walls.

The results presented in Figures 10 and 11 allow us to conclude that, in the event of a crown forest fire, the building will be ignited for any color of the surface of the enclosing structures of a wooden building. Moreover, the critical temperature is already reached at an exposure time of $50 \mathrm{~s}$. The front of a crown forest fire spreads too fast.

Analyzing the results presented in Figure 12, it is clear that the ignition of a wooden building under the influence of a crown forest fire will most likely occur at a certain height from the land surface. Here, the scenario of modeling the height of the impact of a crown forest fire from 1 to $10 \mathrm{~m}$ should be explained. According to the legislation of the Russian Federation, individual housing construction of buildings with a height of no more than three floors is allowed. This applies to both urban and rural development [62]. This is approximately a height of about $10 \mathrm{~m}$. Figure 12 shows that, at the soil surface, the surface temperature of the building enclosure is minimal. There is a drain of heat into the foundation and the soil layer around the building.

Figure 13 shows the results of modeling the impact of the surface forest fire of low intensity, which has the shape of an elongated egg. The software utility implemented a parabolic dependence of the forest fire's contour on the horizontal coordinate. The shape of the surface forest fire front, elongated in the center, causes an increase in the surface temperature of the building envelope on the localization line of the apex of the parabolic front of the surface forest fire. Moreover, the most noticeable effect is on a building enclosure that is not lined with any cladding.

Figure 14 shows the results of modeling the impact of a parabolic front of a surface forest fire of high intensity. The result is also logical when ignition occurs on the localization line of the top of the parabolic front of a forest fire. With any cladding materials, critical temperatures are reached at which the ignition of wood or wood-glued materials occurs.

Table A1 shows the main scenarios of the impacts of forest fires on the enclosing structures of a wooden building. Additionally given are the calculated values of the density of the radiant heat flux from the front of the forest fire to the surface of the building, depending on the exposure time. In addition, data are presented that establish the fact of ignition of the enclosing structure of a wooden building. Only exposure to radiant heat flux is considered. Direct flame contact and firebrands are not considered in this work. Depending on the distance from the front of the forest fire to the walling, a certain heat flux acts on the wall surface. As a rule, a surface forest fire of low intensity does not pose a great danger to the functioning of an industrial facility or residential building unless the front of a forest fire comes close enough to the enclosing structures of a wooden building. In most cases, a high-intensity surface forest fire is a danger to wooden buildings, and early measures are required to prevent a forest fire from transitioning to a wooden building. Crown forest fires may expose wooden buildings to extreme danger.

The purpose of the proposed mathematical model for simulating the thermal effect of a forest fire on the enclosing structures of a wooden building should be clearly understood. The model is quite simple, but it allows one to get a number of interesting results that can be used in practice in the fight against fires in WUI zones. Analogs of other authors allow us to simulate not only heat transfer, but also mass transfer, pyrolysis, and the formation of pyrolysis products. The present model focuses on the formation of a temperature field in the enclosing structure of a wooden building. It should be understood that, at present, the main attention is paid to predicting forest fire danger, including in the territory of the Republic of Buryatia (Russian Federation) in the vicinity of Lake Baikal. For the purposes of monitoring and predicting forest fires and burned areas in the Russian 
Federation, the Information System for Remote Monitoring of Forest Fires, ISDM-Rosleskhoz [63], is used. This system has accumulated data on the forest fund, and also includes modules for calculating the probability of forest fires from thunderstorms and anthropogenic load, taking into account weather data [64]. The Nesterov criterion [65] is used together with the probabilistic criteria [66]. The minimal territorial unit is the area of responsibility of a separate weather station. Moreover, the network of weather stations in Siberia and the Far East is quite sparse. This leads to the fact that forest conditions are averaged over a rather large area, and it is impossible to apply mathematical models of the spread of forest fires based, for example, on the mechanics of multiphase reacting media [67]. In fact, the user can get from ISDM-Rosleskhoz only the location, the speed of the forest fire, and the distance to the village or industrial facility. In this case, it is justified to use parametric modeling of the propagation of the forest fire front, and not to use mathematical models based on the Navier-Stokes equations. Regarding the use of advanced mathematical models, such as Gpyro [52], the situation is somewhat similar. To operate such models, accurate data on building materials and the geometric characteristics of building enclosures are needed. Only in this case, it is justified to use mathematical models that allow precision modeling to be performed, taking into account the processes of heat and mass transfer, pyrolysis, and gas-phase chemical reactions. Concerning the practical application of the mathematical model, it must be understood that there are no data on the wooden buildings of rural settlements, campsites, or industrial facilities in the ISDM-Rosleskhoz.

It is advisable to carry out simplified modeling using the scenario approach [66]. In this case, one can set approximate characteristics of the enclosing structures of a wooden building and consider various scenarios of the effects of a forest fire based on its characteristics that are available in ISDM-Rosleskhoz. Despite the simplicity, the proposed mathematical model allows one to obtain results, for example, on the influence of the height and shape of the forest fire front on heat transfer processes in the enclosing structures of a wooden building, that is, to take into account the spatial structure of the approaching forest fire front.

Thus, the developed software utility has a clear practical orientation, but the results of its application are adequate, both from the point of view of using normative and technical documentation, and the positions of thermal physics of forest fires [68,69]. The combined use of GIS technologies [70-73] and remote sensing methods [74-78] can give excellent results in monitoring and predicting the fire safety of industrial facilities and residential buildings in rural settlements and campsites in the conditions of active forest fires.

\section{Conclusions}

An important scientific and application-oriented problem was solved in this study, namely, the creation of an engineering approach to monitor sustainable functioning and development of rural settlements, industrial facilities, and recreational areas based on scenario modeling of the impact of a forest fire front on the building enclosures of a wooden building using a simplified physically sound mathematical model of heat transfer. As criteria for ignition, experimental data [56] were used on the surface temperature and the magnitude of the radiant heat flux directed to this surface. This paper also presents generalized equations for calculating the density of the radiant heat flux from the front of a surface or crown forest fire depending on the distance from the building and the height of the fire front. It should be noted that the working range of these formulas is limited by the conditions of use used in this article. These equations can also be applicable for the assessment of forest fires' environmental impact on forest stands and biodiversity in the context of sustainable development of forested territories [79].

As a result of scenario modeling, temperature distributions in the "cladding-facade" system were established for various cladding materials, the distance from the front of the forest fire to the building enclosure, and the fire's speed and height. In the course of the study, thermophysical characteristics were used, which are indicated in state standards [11]. In fact, for the first time for the dry zone of the Russian Federation (the Republic of Buryatia, according to building standards, is referred to as a 
dry climate zone), the results of modeling of heat transfer and ignition of the enclosing structures of wooden buildings of industrial facilities, rural settlements, and campsites under the influence of radiant heat flux from the front of a forest fire were obtained. A three-dimensional simplified mathematical model of heat transfer and ignition is presented, taking into account various properties of cladding materials and the spatial structure of the front of a forest fire. Furthermore, the key findings of this study can be used to assess the sustainability and sustainable development of different objects in WUI zones according to environmental, social, and economic dimensions of forest fire dangers and risk problems. The mathematical model can be used for generation of new GIS systems in conjunction with remote sensing technologies for sustainable management of land [80]. The obtained results, namely, the equations for incident heat flux and the mathematical model, can be also used for public policy design in the context of forest fire danger and owners' responsibilities for sustainability of rural settlements, industrial facilities, and recreational zones.

Author Contributions: Conceptualization, Funding Acquisition, Methodology, Project Administration, Supervision, Investigation, Software, Validation, Visualization, Writing-Original Draft Preparation, Writing-Review and Editing, N.B.; Investigation, Software, Validation, Visualization, Writing - Original Draft Preparation, A.M. All authors have read and agreed to the published version of the manuscript.

Funding: This research was funded by the Russian Foundation for Basic Research, grant number 17-29-05093. The APC was funded by the Russian Foundation for Basic Research.

Conflicts of Interest: The authors declare no conflict of interest.

\section{Appendix A}

Table A1. Glued plywood cladding—forest fire impact scenarios.

\begin{tabular}{|c|c|c|c|c|c|c|}
\hline Scenario & Exposure Time, $\mathrm{s}$ & Distance, $\mathrm{m}$ & Height, $\mathrm{m}$ & Forest Fire Velocity, m/s & Heat Flux, kW/m ${ }^{2}$ & Ignition \\
\hline 1 & 50 & 20 & 1 & 0.015 & 0.980 & No \\
\hline 2 & 50 & 20 & 1.5 & 0.015 & 1.024 & No \\
\hline 3 & 50 & 20 & 1 & 0.05 & 1.437 & No \\
\hline 4 & 50 & 20 & 1.5 & 0.05 & 1.473 & No \\
\hline 5 & 50 & 20 & 1 & 0.33 & 61.478 & Yes \\
\hline 6 & 50 & 20 & 3 & 0.33 & 96.3 & Yes \\
\hline 7 & 50 & 20 & 5 & 0.33 & 110.839 & Yes \\
\hline 8 & 50 & 20 & 7 & 0.33 & 125.254 & Yes \\
\hline 9 & 50 & 20 & 10 & 0.33 & 147.417 & Yes \\
\hline 10 & 50 & 20 & 15 & 0.33 & 163.138 & Yes \\
\hline
\end{tabular}

Table A2. Glued plywood cladding-heat loss and painting scenarios (surface forest fire).

\begin{tabular}{|c|c|c|c|c|c|}
\hline Scenario & Exposure Time, s & Distance, $\mathrm{m}$ & Height, m & Painting & Heat Loss \\
\hline 1 & 50 & 20 & 1 & Dark gray & No \\
\hline 2 & 50 & 20 & 1 & Dark gray & Yes \\
\hline 3 & 50 & 20 & 1 & Lime paint & No \\
\hline 4 & 50 & 20 & 1 & Lime paint & Yes \\
\hline 5 & 50 & 20 & 1 & Blue & No \\
\hline 6 & 50 & 20 & 1 & Blue & Yes \\
\hline 7 & 50 & 20 & 1 & White & No \\
\hline 8 & 50 & 20 & 1 & White & Yes \\
\hline 9 & 50 & 20 & 1 & Wood & No \\
\hline 10 & 50 & 20 & 1 & Wood & Yes \\
\hline
\end{tabular}


Table A3. Glued plywood cladding—heat loss and painting scenarios (crown forest fire).

\begin{tabular}{cccccc}
\hline Scenario & Exposure Time, $\mathbf{s}$ & Distance, $\mathbf{m}$ & Height, $\mathbf{m}$ & Painting & Heat Loss \\
\hline 1 & 50 & 20 & 1 & Dark gray & No \\
\hline 2 & 50 & 20 & 1 & Dark gray & Yes \\
\hline 3 & 50 & 20 & 1 & Lime paint & No \\
\hline 4 & 50 & 20 & 1 & Lime paint & Yes \\
\hline 5 & 50 & 20 & 1 & Blue & No \\
\hline 6 & 50 & 20 & 1 & Blue & Yes \\
\hline 7 & 50 & 20 & 1 & White & No \\
\hline 8 & 50 & 20 & 1 & White & Yes \\
\hline 9 & 50 & 20 & 1 & Wood & No \\
\hline 10 & 50 & 20 & 1 & Wood & Yes \\
\hline
\end{tabular}

Table A4. Glued plywood cladding-forest fire characteristic influence scenarios.

\begin{tabular}{ccccc}
\hline Scenario & Exposure Time, $\mathbf{s}$ & $\mathbf{T}_{\mathbf{f f}}, \mathbf{K}$ & Line Front & Parabola Front, Center \\
\hline 1 & 425 & 900 & Yes & 20 \\
\hline 2 & 425 & 1000 & Yes & 20 \\
\hline 3 & 50 & 1200 & Yes & 20 \\
\hline 4 & 425 & 900 & Yes & 18 \\
\hline 5 & 425 & 1000 & Yes & 18 \\
\hline 6 & 50 & 1200 & Yes & 16 \\
\hline 7 & 425 & 900 & Yes & 16 \\
\hline 8 & 425 & 1000 & Yes & 16 \\
\hline 9 & 50 & 1200 & Yes &
\end{tabular}

\section{References}

1. Baranovskiy, N.V.; Kuznetsov, G.V. Forest Fire Occurrences and Ecological Impact Prediction: Monograph; Publishing House of the Siberian Branch of the Russian Academy of Science: Novosibirsk, Russia, 2017.

2. Mell, W.E.; Manzello, S.L.; Maranghides, A.; Butry, D.; Rehm, R.G. The wildland-urban interface fire problem-Current approaches and research needs. Int. J. Wildland Fire 2010, 19, 238-251. [CrossRef]

3. Rehm, R.G. The Effects of Winds from Burning Structures on Ground-Fire Propagation at the Wildland-Urban Interface; Report GCR 06-892; National Institute of Standards and Technology: Gaithersburg, MD, USA, 2008; pp. 1-31.

4. Valendik, E.N.; Kosov, I.V. Effect of thermal radiation of forest fire on the environment. Contemp. Probl. Ecol. 2008, 1, 399-403. [CrossRef]

5. Cohen, J.D. Preventing disaster: Home ignitability in the wildland-urban interface. J. For. 2000, 98, 15-21.

6. Microsoft Visual Studio. Available online: https://visualstudio.microsoft.com (accessed on 3 April 2020).

7. RAD Studio. Available online: https://www.embarcadero.com/ru/products/rad-studio (accessed on 3 April 2020).

8. Matlab. Available online: https://www.mathworks.com/products/matlab.html (accessed on 3 April 2020).

9. ANSYS. Available online: https://www.ansys.com/ (accessed on 3 April 2020).

10. Schetinskiy, E.A. Sputnik of the Head for Extinguishing Forest Fires; VNIILM: Moscow, Russia, 2003; 96p. (In Russian)

11. Thermal Performance of the Buildings; SNiP 23-02-2003; Gosstroy: Moscow, Russia, 2003. (In Russian)

12. Yankovich, K.S.; Yankovich, E.P.; Baranovskiy, N.V. Classification of Vegetation to Estimate Forest Fire Danger Using Landsat 8 Images: Case Study. Math. Probl. Eng. 2019, 2019, 6296417. [CrossRef] 
13. Baranovskiy, N.V. Mathematical Simulation of Anthropogenic Load on Forested Territories for Point Source. In Predicting, Monitoring, and Assessing Forest Fire Dangers and Risks; Baranovskiy, N.V., Ed.; IGI Global: Hershey, PA, USA, 2020; pp. 64-88. [CrossRef]

14. Radeloff, V.C.; Hammer, R.B.; Stewart, S.I.; Fried, J.S.; Holcomb, S.S.; McKeefry, A.J. The wildland-urban interface in the United States. Ecol. Appl. 2005, 15, 799-805. [CrossRef]

15. Nowak, D.J.; Walton, J.T. Projected urban growth (2000-2050) and its estimated impact on the US forest resource. J. For. 2005, 103, 383-389.

16. Hammer, R.B.; Radeloff, V.C.; Fried, J.S.; Stewart, J.S. Wildland-urban interface housing growth during the 1990s in California, Oregon, and Washington. Int. J. Wildland Fire 2007, 16, 255-265. [CrossRef]

17. Sturtevant, B.R.; Cleland, D.T. Human and biophysical factors influencing modern fire disturbance in northern Wisconsin. Int. J. Wildland Fire 2007, 16, 398-413. [CrossRef]

18. Syphard, A.D.; Radellof, V.C.; Keely, J.E.; Hawbaker, T.J.; Clayton, M.K.; Stewart, S.I.; Hammer, R.B. Human influence on California fire regimes. Ecol. Appl. 2007, 17, 1388-1402. [CrossRef]

19. Arno, S.F.; Brown, J.K. Managing fire in our forests-Time for a new alternative. J. For. 1989, 87, 44-46.

20. Bevers, M.; Omi, P.N.; Hof, J. Random location of fuel treatments in wildland community interfaces: A percolation approach. Can. J. For. Res. 2004, 34, 164-173. [CrossRef]

21. Andrews, P.; Bevins, C. Update and expansion of the BEHAVE fire behaviour prediction systems. In Proceedings of the 14th Conference on Forest Fire Research and 14th Conference on Fire and Forest Meteorology, Luso, Coimbra, Portugal, 16-20 November 1998; Viegas, D., Ed.; ADAI, University of Coimbra: Coimbra, Portugal, 1998; Volume 1, pp. 733-740.

22. Burgan, R.; Klaver, R.; Klaver, J. Fuel model and fire potentional from satellite and surface observations. Int. J. Wildland Fire 1998, 8, 159-170. [CrossRef]

23. Wylie, B.; Meyer, D.; Tieszen, L.; Mannel, S. Satellite mapping of surface biophysical parameters at the biome scale over North American grasslands: A case study. Remote Sens. Environ. 2002, 79, 266-278. [CrossRef]

24. Chou, Y.; Chase, R. Mapping probability of fire occurrence in San Jacinto mountains, California, USA. Environ. Manag. 1993, 17, 129-140. [CrossRef]

25. Preisler, H.; Brillinger, D.; Burgan, R.; Benoit, J. Probably based models for estimation of wildfire risk. Int. J. Wildland Fire 2004, 13, 133-142. [CrossRef]

26. Lowell, K.; Shamir, R.; Siqueira, A.; White, J.; O'Connor, A.; Butcher, G.; Garvey, M.; Niven, M. Assessing the capabilities of geospatial data to map built structures and evaluate their bushfire threat. Int. J. Wildland Fire 2009, 18, 1010-1020. [CrossRef]

27. National Interagency Fire Center. Federal Firefighting Costs (Suppression Only). (Boise, ID). Available online: https://www.nifc.gov/fireInfo/fireInfo_documents/SuppCosts.pdf (accessed on 4 June 2020).

28. National Interagency Fire Center. Historic Data Comparisons (Boise, ID). Available online: https://www. predictiveservices.nifc.gov/intelligence/2018_statssumm/intro_summary18.pdf (accessed on 4 June 2020).

29. Mell, W.; Jenkins, M.A.; Gould, J.; Cheney, P. A physics-based approach to modeling grassland fires. Int. J. Wildland Fire 2007, 16, 1-22. [CrossRef]

30. Rehm, R.G.; Mell, W. A simple model for wind effects of burning structures and topography on wildland-urban interface surface-fire propagation. Int. J. Wildland Fire 2009, 18, 290-301. [CrossRef]

31. Cachim, P.B.; Franssen, J.M. Numerical modelling of timber connection under fire loading using a component model. Fire Saf. J. 2009, 44, 840-853. [CrossRef]

32. Regueira, R.; Guaita, M. Numerical simulation of the fire behavior of timber dovetail connections. Fire Saf. J. 2018, 96, 1-12. [CrossRef]

33. Schnabl, S.; Turk, G.; Planinc, I. Buckling of timber columns exposed to fire. Fire Saf. J. 2011, 46, 431-439. [CrossRef]

34. Ali, F.; Kavanagh, S. Fire resistance of timber columns. J. Inst. Wood Sci. 2005, 17, 85-93. [CrossRef]

35. Lie, T.T. A methods for assessing the fire resistance of laminated timber beams and columns. Can. J. Civ. Eng. 1997, 4, 161-169. [CrossRef]

36. Purkiss, J.A. Fire Safety Engineering Design of Structures, 2nd ed.; Elsevier/Butterworth-Heinemann: Oxford, UK, 2007.

37. Manzello, S.L.; Park, S.H.; Cleary, T.G. Development of rapidly deployable instrumentation packages for data acquisition in wildland-urban interface (WUI) fires. Fire Saf. J. 2010, 45, 327-336. [CrossRef] 
38. Cheng, H.; Hadjisophocleous, G.V. The modeling of fire spread in building by Bayesian network. Fire Saf. J. 2009, 44, 901-908. [CrossRef]

39. Lennon, T.; Silberschmidt, V. Large scale natural fire tests on protected engineered timber floor systems. Fire Saf. J. 2010, 45, 168-182. [CrossRef]

40. Frangi, A.; Fontana, M.; Hugi, E.; Jöbstl, R. Experimental analysis of cross-lamionated timber panels in fire. Fire Saf. J. 2009, 44, 1078-1087. [CrossRef]

41. Himoto, K.; Shinohara, M.; Sekizawa, A.; Takanashi, K.; Hitomu, S. A field experiment on fire spread within a group of model houses. Fire Saf. J. 2018, 96, 105-114. [CrossRef]

42. DiDomizio, M.J.; Mulherin, P.; Weckman, E.J. Ignition of wood under time-varying radiant exposures. Fire Saf. J. 2016, 82, 131-144. [CrossRef]

43. Janssens, M.L. Piloted ignition of wood: A review. Fire Master 1991, 15, 151-167. [CrossRef]

44. Delichatsios, M.A.; Panagiotou, T.; Kiley, F. The use of time to ignition data for characterizing the thermal inertia and the minimun (critical) heat flux for ignition or pyrolysis. Combust. Flame 1991, 84, 323-332. [CrossRef]

45. Delichatsios, M.A.; Paroz, B.; Bhargava, A. Flammability properties for charring materials. Fire Saf. J. 2003, 38, 219-228. [CrossRef]

46. Spearpoint, M.J.; Quintiere, J.G. Predicting the piloted ignition of wood in the cone calorimeter using an integral model-effect of species, grain orientation and heat flux. Fire Saf. J. 2001, 36, 391-415. [CrossRef]

47. Dietenberger, M.A.; Boardman, C.R. EcoSmart Fire as structure ignition model in wildland urban interface: Predictions and validations. Fire Technol. 2016, 53, 577-607. [CrossRef]

48. Tran, T.T.; Khelifa, M.; Nadjai, A.; Oudjene, M.; Rogaume, Y. Modelling of fire performance of Cross Laminated Timber (CLT) panels. J. Phys. Conf. Ser. 2018, 1107, 032002. [CrossRef]

49. Abaqus. Finite Element Modelling Programme and Standard User's Manual; Version 6.14; SIMULIA: Johnston, RI, USA, 2016.

50. Turner, I.; Rousset, P.; Remond, R.; Perre, P. An experimental and theoretical investigation of the thermal treatment of wood (Fagus sylvatica L.) in the range 200-260 ${ }^{\circ}$ C. Int. J. Heat Mass Transf. 2010, 53, 715-725. [CrossRef]

51. Younsi, R.; Kocaefe, D.; Poncsak, S.; Kocaefe, Y. Thermal modeling of the high temperature treatment of wood based on Luikov's approach. Int. J. Energy Res. 2006, 30, 699-711. [CrossRef]

52. Lautenberger, C.; Fernandez-Pello, C. A model for the oxidative pyrolysis of wood. Combust. Flame 2009, 156, 1503-1513. [CrossRef]

53. Samarskii, A.A.; Vabishchevich, P.N. Computational Heat Transfer; Mathematical Modelling; Wiley: Chichester, UK, 1995; Volume 1, 418p.

54. Samarskii, A.A.; Vabishchevich, P.N. Computational Heat Transfer; The Finite Difference Method; Wiley: Chichester, UK, 1995; Volume 2, 432p.

55. Badmaev, N.B.; Bazarov, A.V.; Sychev, R.S. Forest Fire Danger Assessment Using Meteorological Trends: Case Study. In Predicting, Monitoring, and Assessing Forest Fire Dangers and Risks; Baranovskiy, N.V., Ed.; IGI Global: Hershey, PA, USA, 2020; pp. 183-208. [CrossRef]

56. Zabolotnyi, A.E.; Zabolotnaya, M.M.; Timoshin, V.N. Determining the regions of safe use of solidfuel generators of fire-extinguishing aerosols. Issues Spec. Eng. 1995, 7, 15-22. (In Russian)

57. Goman, P.N. The Dynamics of Surface Forest Fire and Forest Fuel Ignition under the Heat Radiation from the Fire Line. In Predicting, Monitoring, and Assessing Forest Fire Dangers and Risks; Baranovskiy, N.V., Ed.; IGI Global: Hershey, PA, USA, 2020; pp. 1-47. [CrossRef]

58. Lesnoy Dozor Software Hardware Complex. Available online: http://lesdozor.ru/en/ (accessed on 4 June 2020).

59. Brunette, M.; Couture, S.; Foncel, J.; Garcia, S. The decision to insure against forest fire risk: An econometric analysis combining hypothetical real data. Geneva Pap. Risk Insur. Issues Pract. 2020, 45, 111-133. [CrossRef]

60. Solodkin, A.S.; Ponomarev, K.O. Mathematical simulation of heat impact of heated up to high temperatures particle on human skin: Simple one-dimensional statement. MATEC Web Conf. 2014, 19, 01034. [CrossRef]

61. Frankenberg, E.; Mckee, D.; Thomas, D. Health consequences of forest fires in Indonesia. Demography 2005, 42, 109-129. [CrossRef] [PubMed]

62. Single-Family Houses; SNiP 31-02-2001; Rosstandart: Moscow, Russia, 2001. (In Russian)

63. Information System for Remote Monitoring of Forest Fires ISDM-Rosleskhoz. Official Site. Available online: https://nffc.aviales.ru/main_pages/index.shtml (accessed on 3 June 2020). 
64. Podolskaya, A.S.; Ershov, D.V.; Shulyak, P.P. Application of the method for assessing the probability of occurrence of forest fires in ISDM-Rosleskhoz. Mod. Probl. Remote Sens. Earth Space 2011, 8, 118-126. (In Russian)

65. Nesterov, V.G. Forest Combustibility and Methods for Its Determination; Goslesbumizdat: Moscow, Russia, 1949; 76p. (In Russian)

66. Baranovskiy, N.; Zharikova, M. A web-oriented geoinformation system application for forest fire danger prediction in typical forests of the Ukraine. Lect. Notes Geoinf. Cartogr. 2014, 13-22. [CrossRef]

67. Nigmatulin, R.I. Dynamics of Multiphase Media; Part 1; Nauka: Moscow, Russia, 1987; 446p. (In Russian)

68. Grishin, A.M. Mathematical Modeling of Forest Fire and New Methods of Fighting Them; Publishing House of the Tomsk State University: Tomsk, Russia, 1997; 390p.

69. Baranovskiy, N.; Demikhova, A. Mathematical modeling of heat transfer in an element of combustible plant material when exposed to radiation from a forest fire. Safety 2019, 5, 56. [CrossRef]

70. Glagolev, V.A.; Zubareva, A.M. The system of regional forecast fire danger of vegetation on natural and anthropogenic conditions. Proc. SPIE-Int. Soc. Opt. Eng. 2019, 11208, 112087B. [CrossRef]

71. Rashid, K.J.; Hoque, M.A.; Esha, T.A.; Rahman, M.A.; Paul, A. Spatiotemporal changes of vegetation and land surface temperature in the refugee camps and its surrounding areas of Bangladesh after the Rohingya influx from Myanmar. Environ. Dev. Sustain. 2020. [CrossRef]

72. Adab, H. Landfire hazard assessment in the Caspian Hyrcanian forest ecoregion with the long-term MODIS active fire data. Nat. Hazards 2017, 87, 1807-1825. [CrossRef]

73. Eskandari, S. A new approach for forest fire risk modeling using fuzzy AHP and GIS in Hyrcanian forests of Iran. Arab. J. Geosci. 2017, 10, 190. [CrossRef]

74. Qiao, C.; Wu, L.; Chen, T.; Huang, Q.; Li, Z. Study on Forest Fire Spreading Model Based on Remote Sensing and GIS. IOP Conf. Ser. Earth Environ. Sci. 2018, 199, 022017. [CrossRef]

75. Santi, E.; Paloscia, S.; Pettinato, S.; Fontanelli, G.; Mura, M.; Zolli, C.; Maselli, F.; Chiesi, M.; Bottai, L.; Chirici, G. The potential of multifrequency SAR images for estimating forest biomass in Mediterranean areas. Remote Sens. Environ. 2017, 200, 63-73. [CrossRef]

76. Frazier, R.J.; Coops, N.C.; Wulder, M.A.; Hermosilla, T.; White, J.C. Analyzing spatial and temporal variability in short-term rates of post-fire vegetation return from Landsat time series. Remote Sens. Environ. 2018, 205, 32-45. [CrossRef]

77. Shikhov, A.N.; Perminova, E.S.; Perminov, S.I. Satellite-based analysis of the spatial patterns of fire- and storm-related forest disturbances in the Ural region, Russia. Nat. Hazards 2019, 97, 283-308. [CrossRef]

78. Yang, X.; Yu, Y.; Hu, H.; Sun, L. Moisture content estimation of forest litter based on remote sensing data. Environ. Monit. Assess. 2018, 190, 421. [CrossRef] [PubMed]

79. Lee, H.-J.; Kim, E.-J.; Lee, S.-W. Examining Spatial Variation in the Effects of Japanese Red Pine (Pinus densiflora) on Burn Severity Using Geographically Weighted Regression. Sustainability 2017, 9, 804. [CrossRef]

80. Busico, G.; Giuditta, E.; Kazakis, N.; Colombani, N. A Hybrid GIS and AHP Approach for Modelling Actual and Future Forest Fire Risk Under Climate Change Accounting Water Resources Attenuation Role. Sustainability 2019, 11, 7166. [CrossRef]

(C) 2020 by the authors. Licensee MDPI, Basel, Switzerland. This article is an open access article distributed under the terms and conditions of the Creative Commons Attribution (CC BY) license (http://creativecommons.org/licenses/by/4.0/). 